\title{
A VISUAL ASSESSMENT OF THE CONCRETE VAULTS WHICH SURROUND UNDERGROUND WASTE STORAGE TANKS(U)
}

\author{
B. J. WIERSMA \\ SAVANNAH RIVER TECHNOLOGY CENTER \\ Equipment \& Materials Technology Department \\ Materials Technology Section \\ M. S. SHURRAB \\ HIGH LEVEL WASTE ENGINEERING \\ Technical Support Group
}

Publication Date: December, 1993

\section{Westinghouse Savannah River Company Sovannah River Slie Alken, SC 29808}

This document was prepered in connection with wodk done under Contract No. DE-AC09-89SR18035 with the U. S. Department of Energy. By acceptance of this document, the publisher and/or recipient acknowledges the U. S. Government's right to retain a nonexclusive, royalty-free livense in and to any copyright covering this document, along with the right to reproduce and authorize others to reproduce all or part of the copyrighted material. 


\section{DISCLAIMER}

This report was prepered by Weetinghouse Sovennch Diver Company (WSRC) for tho Unived Siates Depertment of Energy undier Contrect No. DE-ACO\%$89 s 218035$ and $b$ on cecount of work pestormed under that contract. Neither tho Unifod sides Deperiment of Energy, nor WSiC, nor any of their employees

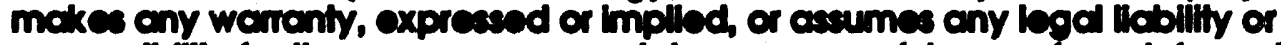
responsibithy for the cccurcey, compieteness, or uectulness, of any information, coperchtue, or product or process dibelosed herein or represents that ths use will not Initinge pitvatchy owned inghts. Reference hereln to any spectile commereled product, process, or service by trademark, nome, monufocturer or otherwise does not necesiartly constitute or imply endorsement, recommendation, or lovoring of scmo by WSRC or by tho United States Government or any agency thereot. The viows and opinions of the cuthors expresesed herein do rot necesearly state or reflect thoes of the United Sidites Government or any agency thereot. 
A VISUAL ASSESSMENT OF THE CONCRETE VAULTS WHICH SURROUND UNDERGROUND WASTE STORAGE TANKS (U)
B. J. Wiersma
M. S. Shurrab

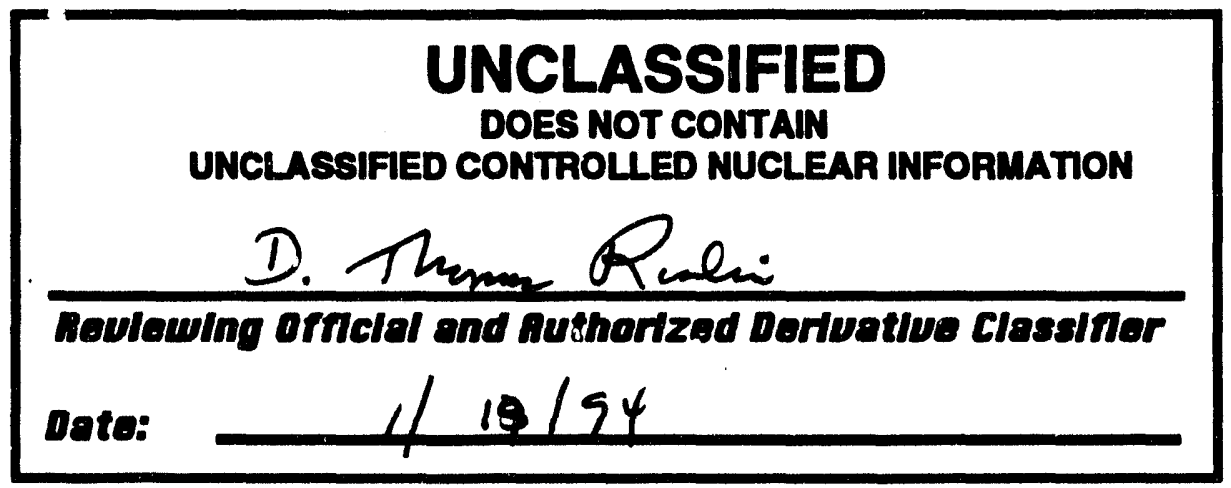

Westinghouse Sovannah Rlver Company Savannah Rlver Slite

Alken, SC 29808

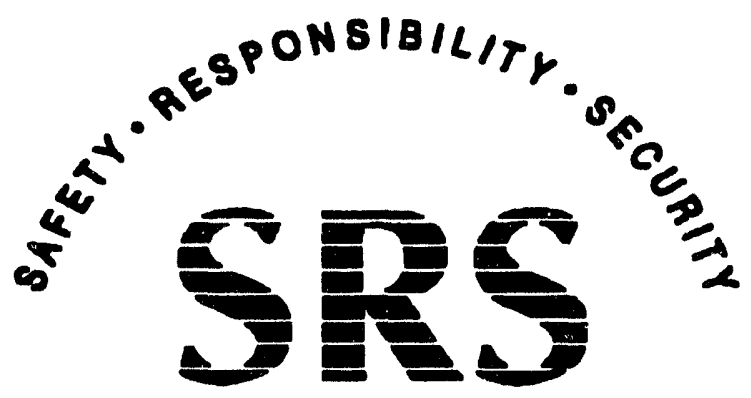

SAVANNAH RIVER SITE 
WSRC-TR-93-761

This page intentionally left blank 


\section{TABLE OF CONTENTS}

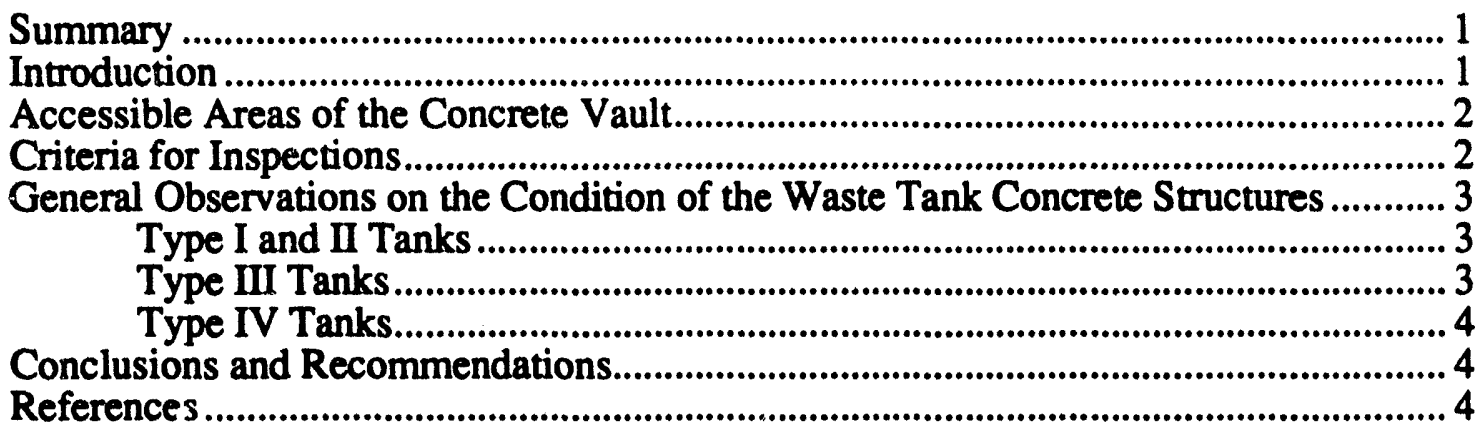

Appendix I Observations of the Concrete Roofs of Type III Waste Tanks ......................24

\section{LIST OF TABLES}

Table 1. Waste Tank Concrete Thickness and Strength...................................................5 Table 2. Description of Accessible and Inaccessible Region of the Waste Tank Concrete 5

\section{LIST OF FIGURES}

Figure 1. Tank design for Type I, II, III, and IV waste tanks. ....................................... 7 Figure 2. Concrete wall in the annulus of Tank 15. Note that the wood form marks show no evidence of degradation.......................................................................... 9 Figure 3. Exposed tie rod in concrete wall of Tank 15. Note that the tie rod shows no evidence of corrosion. ...................................................................................... 11

Figure 4. Drainage trench on Tank 32 roof top................................................................. 13

Figure 5. Scarified region on Tank 37 roof top................................................................ 15

Figure 6. Delamination of patching material on Tank 39 roof top. ................................1 17

Figure 7. Operations to remove concrete slab from the Tank 34 roof top...................... 19

Figure 8. Concrete dome inside Tank 22. Note that the wood form marks show

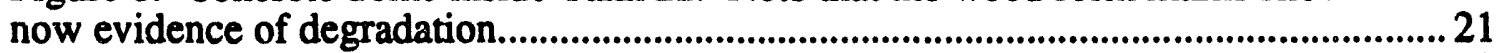

Figure 9. Evidence of calcite leaching inside Tank 23.................................................... 23

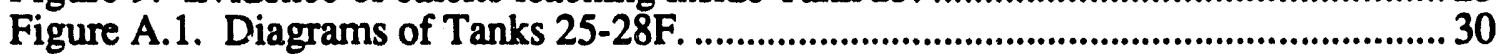

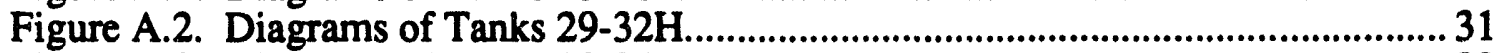

Figure A.3. Diagrams of Tanks 33-34F ……................................................................... 32

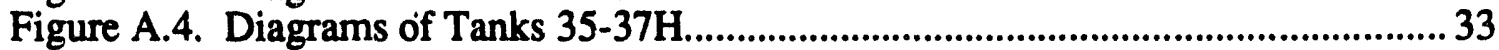

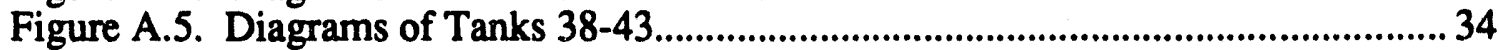

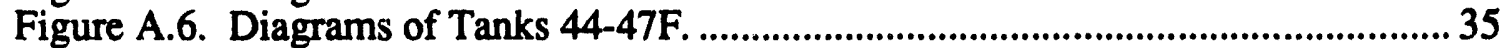

Figure A.7. Diagrams of Tanks 48-51H.......................................................................... 36 
WSRC-TR-93-761 (U)

\section{APPROVALS}

Serue Date:
B.J. Wiersmo. AUTHOR
Materials Applications \& Corrosion Technology Group
MATERIALS TECHNOLOGY SECTION

mazen Shands. Date: 1-17.94 M.S. Shumab, Author

Tehonical Support Group

HIGH LEVEL WASTE ENGINEERING

Rz Hisdolar

R. L. Sindelar, TECHNICAL REVIEWER

Materials Applications \& Corrosion Technology Group

MATERIALS TECHNOLOGY SECTION

Natraj Jy.

Dote: $1-19-94$

N. C. Her, MANAGER

Materials Applications \& Corrosion Technology Group

MATERIALS TECHNOLOGY SECTION

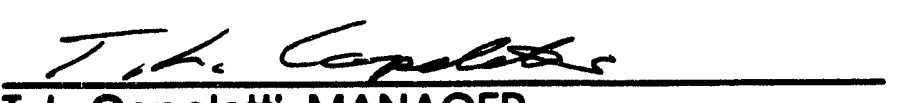

T. L. Capeletti, MANAGER

MATERIALS TECHNOLOGY SECTION

Qhexperan

J. E. Marra, Level 4 MANAGER

Technical Support Group

HIGH LEVEL WASTE ENGINEERING

grchand 0

J. R.Chandler, LEVEL 5 MANAGER

Technical Support Group

HIGH LEVEL WASTE ENGINEERING

Date: If st T4

Dote: $1 / 17 / 94$

Date: 1/17/94 
WSRC-TR-93-761

This page intentionally left blank 


\title{
A Visual Assessment of the Concrete Vaults Which Surround Underground Waste Storage Tanks (U)
}

\author{
B. J. Wiersma \\ and \\ M. S. Shurrab \\ Westinghouse Savannah River Company \\ Savannah River Site \\ Aiken, SC 29808
}

\section{Summary}

As part of the comprehensive WSRC waste tank structural integrity strategy, a study to identify key issues that determine and/or effect the condition of the concrete vaults which surround the underground waste storage tanks. A visual assessment of the accessible regions of the waste tank concrete vaults indicated that no structural degradation has occurred. However, maintenance practices such as trenching, scarifying and patching can be improved.

\section{Introduction}

Radioactive waste produced at the Savannah River Site (SRS) is stored in underground tanks. There are four different waste tank designs (see Figure 1). Type I tanks, which include Tanks 1-12, were built in the early 1950's and have a carbon steel liner surrounded by a five foot high carbon steel pan. Type II tanks, which include Tanks 1316 , were built in the late 1950 's and also have the same double steel containment configuration. Type IV tanks, which include Tanks 17-24, were built the during late 1950 's and early 1960's and have a single steel containment shell. Type III tanks, which include tanks 25-51, were constructed during the late 1960's and 1970's. Type III tanks have a carbon steel primary liner that is surrounded by a secondary carbon steel liner which extends to the roof of the tank. The double shelled tanks contain high heat waste, while the single shell tanks store low heat waste. Design changes were made in the double shelled tanks based on operational experience. The changes were designed to relieve stresses in the materials of construction and minimize stress patterns in the roofing columns. ${ }^{1}$

For each waste tank design the outermost containment shield between the waste and the soil is a concrete vault surrounding the carbon steel liner(s). Should the primary and/or secondary liner be breached, the concrete vault would slow transport of the waste so that contamination of the soil is minimized. The concrete vault dimensions vary depending on the waste tank design (see Table 1). The concrete was reinforced in each tank to withstand stresses due to loading or settlement of the waste tank. All concrete was poured according to codes and engineering standards that were current at the time the waste tanks were constructed.

The Type III waste tanks have a stated design life of 40-60 years. 2 With the uncertainty of the schedule for transfer of the waste to the Defense Waste Processing Facility, it is conceivable that the tanks will be required to function past their design life. The Department of Energy formed a Waste Tank Structural Integrity Panel to investigate the potential for aging and degradation of underground radioactive waste storage tanks employed in the weapons complex. The panel is focusing on how each site in the complex: 1) inspects the waste tanks for degradation, 2) understands the potential 
degradation mechanisms which may occur at their sites, and 3) mitigates the known potential degradation mechanisms. In addition to the carbon steel liners, the degradation of the concrete vault has also been addressed by the panel. High Level Waste Engineering (HLWE) at SRS has formed a task team to identify key issues that determine and/or effect the condition of the concrete.

Initially the team developed a condition survey matrix of attributes which are significant for the assessment of the concrete condition. Second, the team assessed the potential for degradation due to corrosion of the rebar. A literature study was performed to identify mechanisms by which rebar corrodes in concrete and assess factors associated with the concrete quality which may minimize corrosion. ${ }^{3}$ Comprehensive reviews of the engineering specifications that were required for concrete placement and the soil conditions surrounding the tank were performed. The conclusions were that the concrete should not be susceptible to corrosion induced degradation provided the site specifications were followed during the construction of the tanks.

The next initiative of the team was to visually assess the surface condition of the concrete. In June 1993, M. S. Shurrab, B. J. Wiersma, and F. G. McNatt reviewed slides which showed the inside of the concrete vault in Type I, II, and IV tanks. Shurrab and Wiersma subsequently visited the tank farm and assessed the visible portions of the outer concrete vault. Later a team of engineers knowledgeable in concrete degradation (T. W. Houston, C. D. Cowfer, and M. Callahan) performed a walk-down. ${ }^{4}$ Photographs showing the concrete condition were taken at this time. This report summarizes the findings of these walk-downs and reinforces previous recommendations.

\section{Accessible Areas of the Concrete Vault}

Visual assessment of the concrete vault is limited by the design of the underground waste tanks. Table 2 describes the accessible and inaccessible regions for each waste tank type. In general, the outside surface of the concrete vault is inaccessible due to the fact that the tank is buried in the soil. The outer roofs of Type II and III tanks are visible, however, only access to the Type III tanks was attained. To inspect the inner concrete vault, cameras have been designed to photograph the annulus areas. The concrete vault above the annulus pan can be observed in Type I and II tanks. Although these pictures were originally intended to view the tank liner, areas of the concrete may be observed also. For Type I tanks an estimated $25 \%$ of the primary tank liner can be viewed, while for Type II tanks 73-96 \% of the primary is accessible. Additionally, the inner concrete domed roof in the Type IV tanks may be photographed. The latter is significant since the domed roof represents the largest surface area of concrete exposed to the waste vapor. The concrete wall on the inside of Type III tanks is not visible since the carbon steel liner extends to the top of the tank.

\section{Criteria for Inspections}

A determination of the concrete surface condition is neces sary to assess the present condition of the concrete structure. The condition survicy matrix formulated by the WSRC task team focused on eight attributes: (1) general condition of concrete; (2) crack appearance; (3) scaling; (4) spalls and popouts; (5) extent of corrosion or chemical attack; (6) stains; (7) exposed steel, and (8) previous patching or other repair. Observations on these attributes were emphasized during the walk-downs. 


\section{General Observations on the Condition of the Waste Tank Concrete Structures}

\section{Type I and II Tanks}

Photographs of the concrete wall above the annulus were viewed. No signs of degradation were apparent. Figure 2 shows that the wood form marks are still undisturbed forty years after construction. A few exposed tie rods were seen protruding from the wall (see Figure 3 ). There was no evidence that they had corroded. The likely reason that they have not corroded is that the air flow into the annulus maintains a dry environment.

\section{Type III Tanks}

The overall condition of the concrete surface of the roof tops is very good. There were no signs of large cracks, spalls, popouts or corrosion. There was, however, some evidence of poor maintenance procedures and materials on the tank tops. The practices include trenching, scarifying, and patching. The repetition of these practices may artificially increase the natural degradation rate of the concrete.

Trenches were carved into some tank tops to drain excess water and lower the likelihood of spreading contamination (see Figure 4). Six waste tanks $(29-32,36,37)$ on the old hill in $\mathrm{H}$-area have trenches present. It is unknown when the trenches were constructed on these tanks. There are 1-5 trenches present on each of these tank tops. The trenches are between 10-30 feet long, 1/2-3 inches deep, and 5-10 inches wide. Two of the trenches passed through risers. Some of the trenches had been patched and the patching material was delaminating.

Typically three inches of concrete above the rebar is used to provide adequate corrosion protection for the rebar. Trenching reduces the amount of concrete cover above the rebar and thus may expose the rebar to corrosive conditions. Therefore, an alternative to trenching should be developed.

After a spill, the concrete is scarified to remove the coniaminated concrete. A scarified area is shown in Figure 5. Approximately 1/4-1/2 inch of the concrete is scraped from the surface during this process. Thus unless the surface is patched, aggregate is exposed to the environment. Ten tanks in $\mathrm{H}$-area had scarified areas which have not been patched. It was unknown how long the tank tops have been in this condition. During the walkdown in June, Tank 37 had a large scarified area. By October, all the scarified areas had been patched on this tank.

Patching is performed to repair scarified areas. Many of the tanks have patched surfaces; in one case as much as $75 \%$ of the tank top has been patched. Frequently the patching material was observed to be delaminating (see Figure 6). There were also instances where the patching material replaced only a fraction of the original surface depth. A poorly patched surface may result in periodic re-exposure of the aggregate to the environment.

The only case of severe concrete degradation was observed on Tank 34. A four inch, non-reinforced, concrete slab had been placed on the tank top for ancillary equipment. The slab is not a part of the concrete vault. Many cracks were observed near the edge and several chunks of concrete had fallen from the slab. No observations could be made of the reinforced concrete below the slab. Operations were begun to remove this slab in July (see Figure 7). Originally a slab had been placed on Tank 33. This slab had also degraded severely and had been removed prior to the walk downs. The condition of the 
tank top roof appeared adequate; thus there does not seem to be any significant structural damage to the roof due to the degradation of the slab.

Detailed summaries of observations for each Type III tank are presented in Appendix I.

\section{Type IV Tanks}

Photographs of the inner domed concrete roof were viewed. No signs of severe degradation were evident. Figure 8 shows that the wood form marks are still undisturbed thirty years after construction. There was some evidence that a small amount of leaching has occurred. Deposits of calcite were visible at the edge between the concrete dome and the carbon steel liner (see Figure 9). The minimal amount of deposits and the excellent appearance of the concrete, however, indicate that this is an insignificant problem.

\section{Conclusions and Recommendations}

Observations of the accessible regions of the concrete vault indicate that the overall surface condition of the waste tanks is very good. There were no signs of degradation which might lead to structural failure of the concrete vault. In the opinion of the authors, these visual inspections and the discussion of the potential for rebar corrosion ${ }^{2}$ indicates that the concrete vault surrounding the waste tank is structurally sound. Further verification of the materials that were used for construction (i.e., confirmation of as-built materials) and geotechnical analysis to determine the likelihood of settlement will help to verify this assertion.

However, the maintenance of the Type III waste tank tops can be improved. Operations such as trenching, scarifying and patching if not performed correctly may induce unnecessary aging and degradation of the concrete. Studies which would make recommendations to improve the appearance of the tank top and ensure that induced degradation is minimized would be useful.

\section{References}

1. Savannah River Site Waste Tank Corrosion Program (U), WSRC-TR-93-373, September, 1993, Section II p. 12.

2. Double-Shell Tanks for Defense High-Level Radioactive Waste Storage, Final Environmental Impact Statement, DOE/EIS-0062, April 1980.

3. B. J. Wiersma, "An Investigation of the Potential for Corrosion of the Concrete Rebar in the SRS Waste Tanks (U)", WSRC-TR-93-185, March, 1993.

4. T. W. Houston, "Summary of High Level Waste Tank Farm Walk down of July 13, 1993", EPD-SE-93-0212:65, July 28, 1993. 
Table 1. Wraste Tank Concrete Thickness and Strength.

\begin{tabular}{|c|c|c|c|c|c|}
\hline Tank Type & Roof (in) & Wall (in) & Floor (in) & $\begin{array}{c}\text { Earth Cover } \\
\text { (ft) }\end{array}$ & $\begin{array}{c}\text { Compress. } \\
\text { Strength } \\
\text { (psi) }\end{array}$ \\
\hline I & 22 & 22 & 30 & 9 & 2500 \\
\hline II & 45 & 33 & 42 & 0 & $\begin{array}{c}\mathrm{b}-2500 \\
\mathrm{w}-3000\end{array}$ \\
\hline III & 48 & 30 & 42 & 0 & 3000 \\
\hline IV & 7 & 13 & 4 & 3.67 & $\begin{array}{c}\mathrm{b}-3000 \\
\mathrm{w}-5000\end{array}$ \\
\hline
\end{tabular}

b - base slab of structure

w - wall of structure

Table 2. Description of Accessible and Inaccessible Region of the Waste Tank Concrete

\begin{tabular}{|c|c|c|c|}
\hline Tank Design & $\begin{array}{c}\text { Region of Concrete } \\
\text { Vault }\end{array}$ & Accessible & Inaccessible \\
\hline \multirow[t]{2}{*}{ Type I } & Inside & $\begin{array}{l}\text { Concrete vault above the } \\
\text { annulus pan. }\end{array}$ & $\begin{array}{l}\text { Concrete beneath } \\
\text { annulus pan. }\end{array}$ \\
\hline & Outside & N/A & $\begin{array}{l}\text { Tanks are buried } \\
\text { beneath } 8 \text { foot of earth. }\end{array}$ \\
\hline \multirow[t]{2}{*}{ Type II } & Inside & $\begin{array}{l}\text { Concrete vault above the } \\
\text { annulus pan. }\end{array}$ & $\begin{array}{l}\text { Concrete beneath } \\
\text { annulus pan. }\end{array}$ \\
\hline & Outside & N/A & $\begin{array}{l}\text { Unable to see tank tops } \\
\text { due to roped off area and } \\
\text { large amount of } \\
\text { equipment present. }\end{array}$ \\
\hline \multirow[t]{2}{*}{ Type III } & Inside & N/A & $\begin{array}{l}\text { Concrete is beneath a } \\
\text { carbon steel secondary } \\
\text { liner. }\end{array}$ \\
\hline & Outside & Tank top roof. & $\begin{array}{l}\text { Unable to see onter } \\
\text { vault. }\end{array}$ \\
\hline \multirow[t]{2}{*}{ Type IV } & Inside & Domed roof. & $\begin{array}{l}\text { Concrete benisath carbon } \\
\text { steel liner. }\end{array}$ \\
\hline & Outside & $\mathrm{N} / \mathrm{A}$ & $\begin{array}{l}\text { Tanks are buried } \\
\text { beneath approximately } \\
\text { four feet of earth. }\end{array}$ \\
\hline
\end{tabular}


WSRC-TR-93-761

UNCLASSIFIED

Page 6 of 36

This page intentionally left blank 
Figure 1. Tank design for Type I, II, III, and IV waste tanks. 


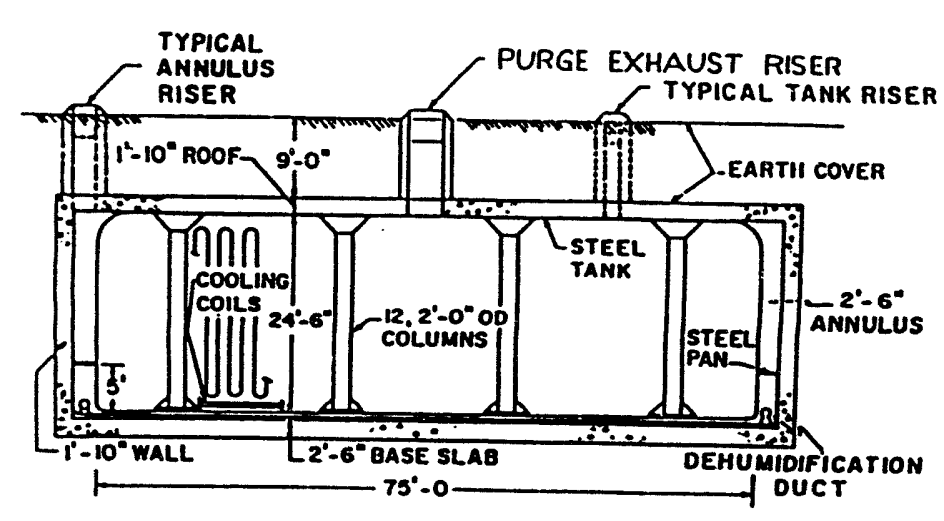

Type I Wasle Tanks

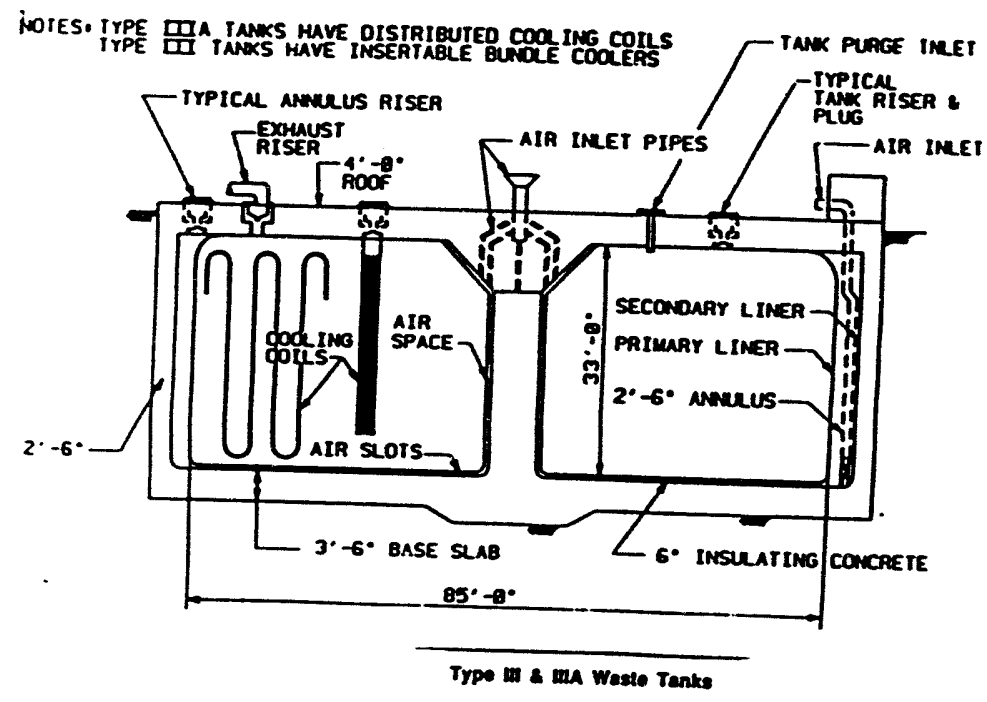

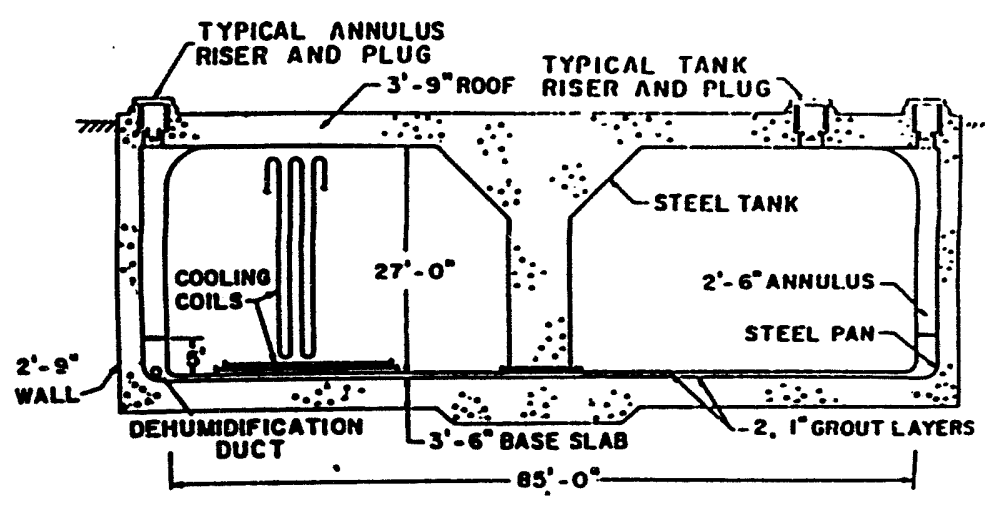

Typo II Westo Tenta

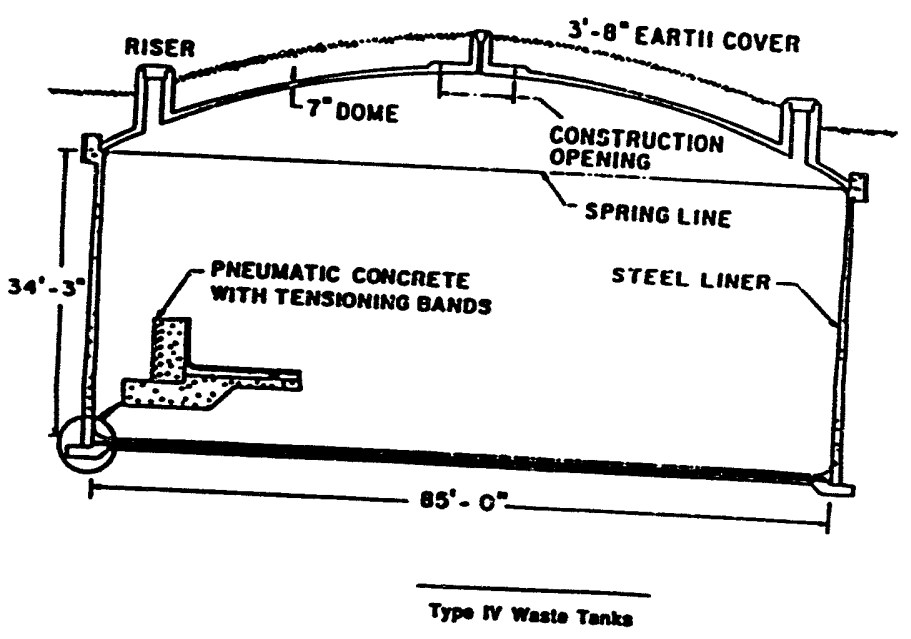


Page 8 of 36

This page intentionally left blank 
Figure 2. Concrete wall in the annulus of Tank 15. Note that the wood form marks show no evidence of degradation. 


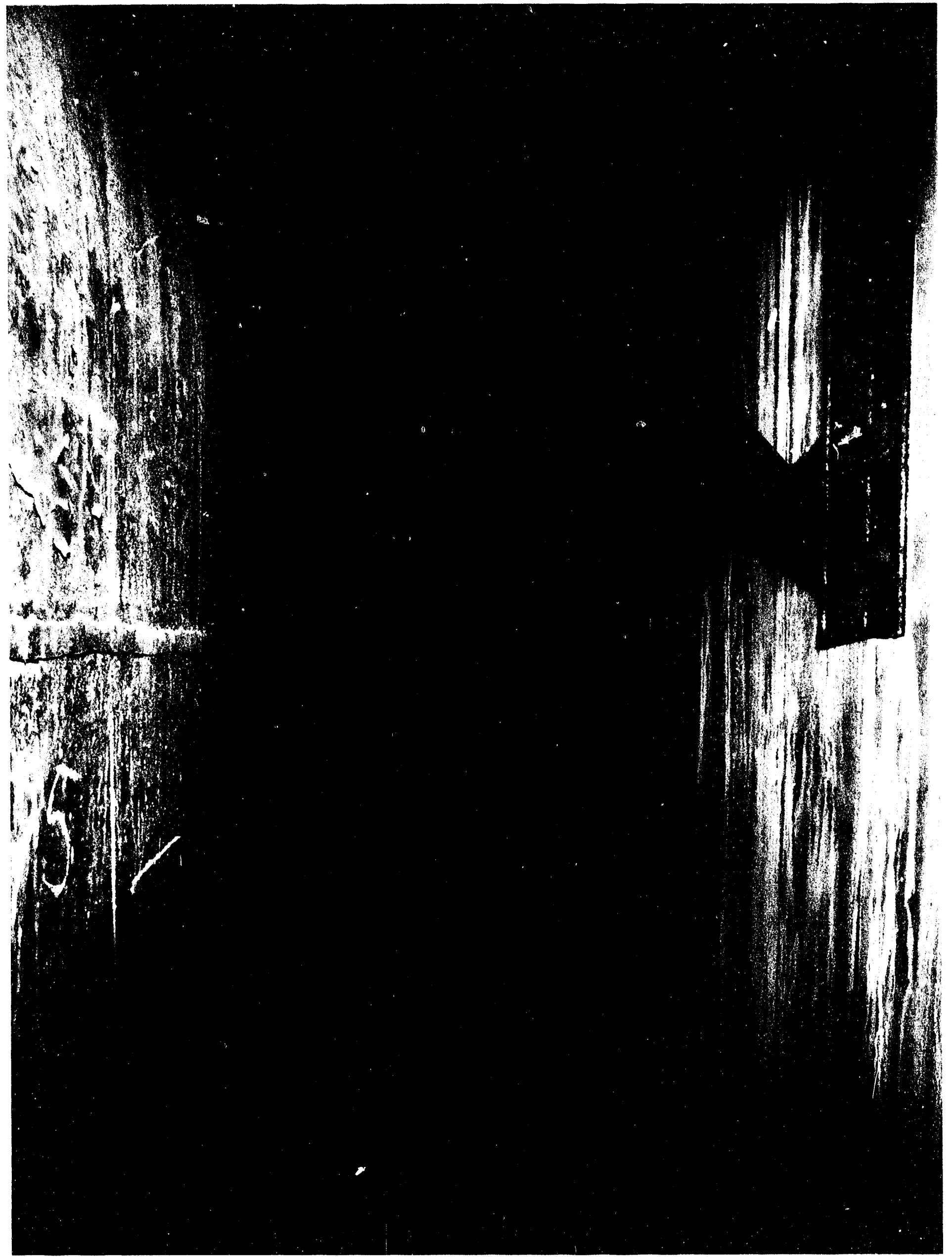


Page 10 of 36

This page intentionally left blank 
Figure 3. Exposed tie rod in concrete wall of Tank 15. Note that the tie rod shows no evidence of corrosion. 


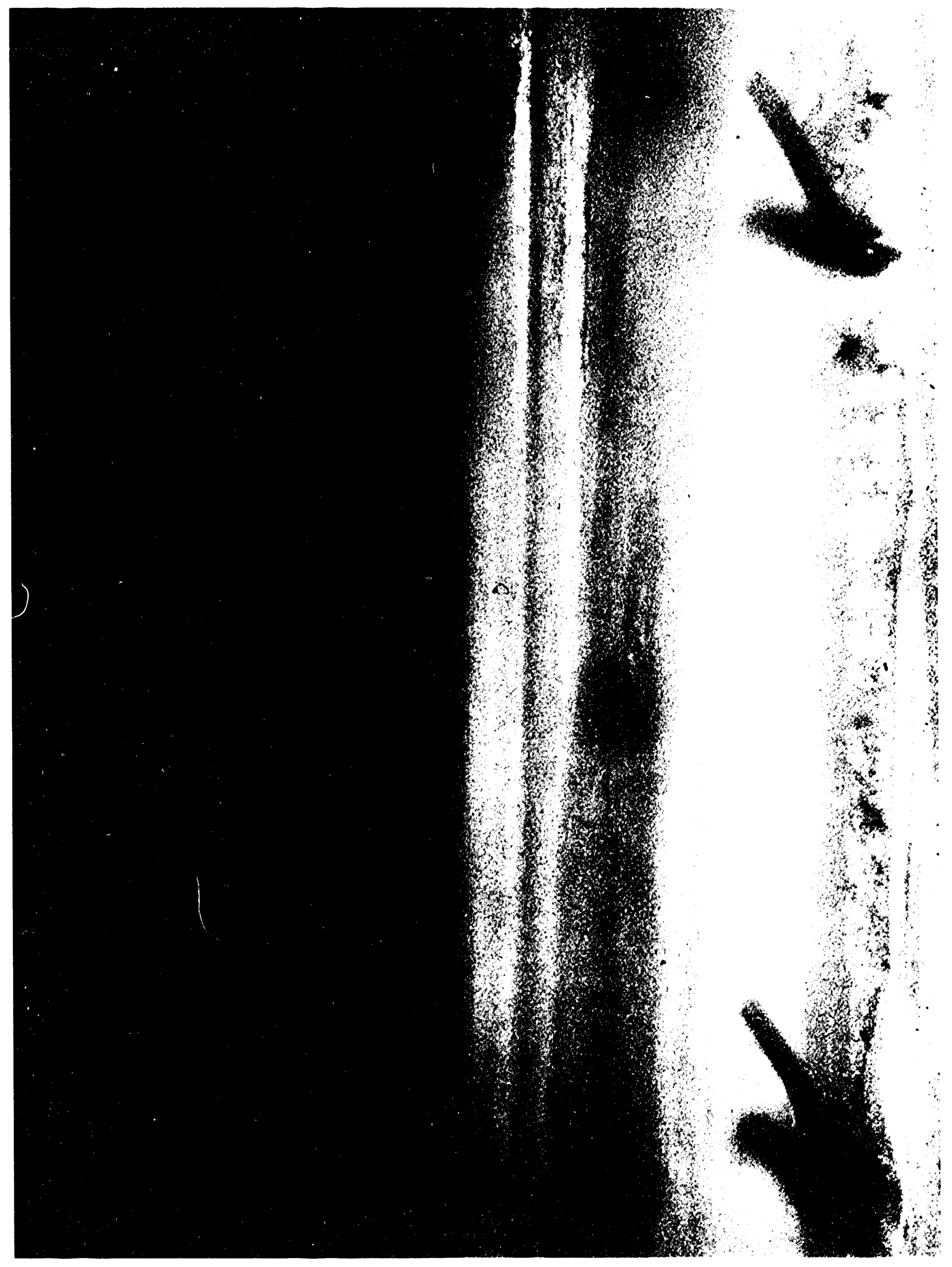


Figure 4. Drainage trench on Tank 32 roof top. 


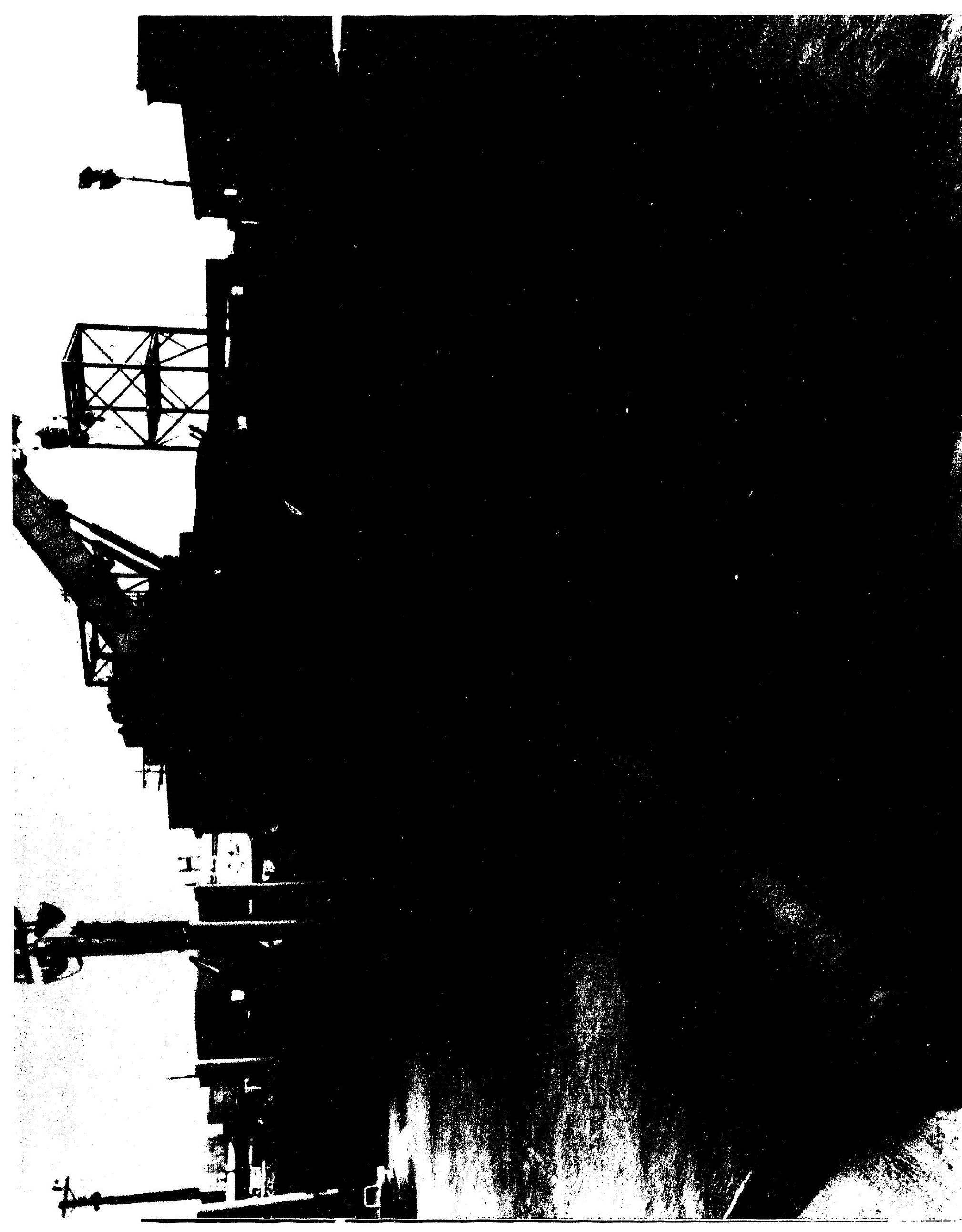


Figure 5. Scarified region on Tank 37 roof top. 


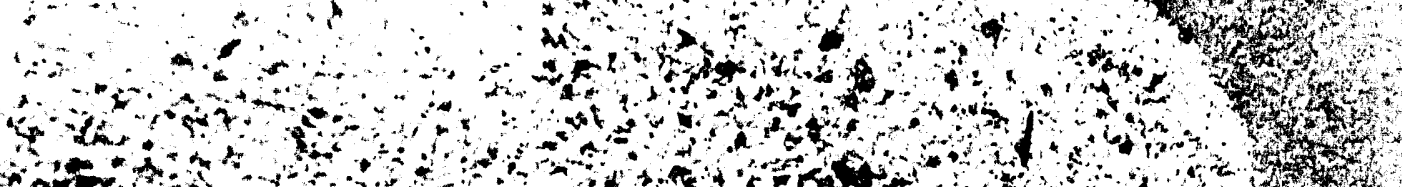

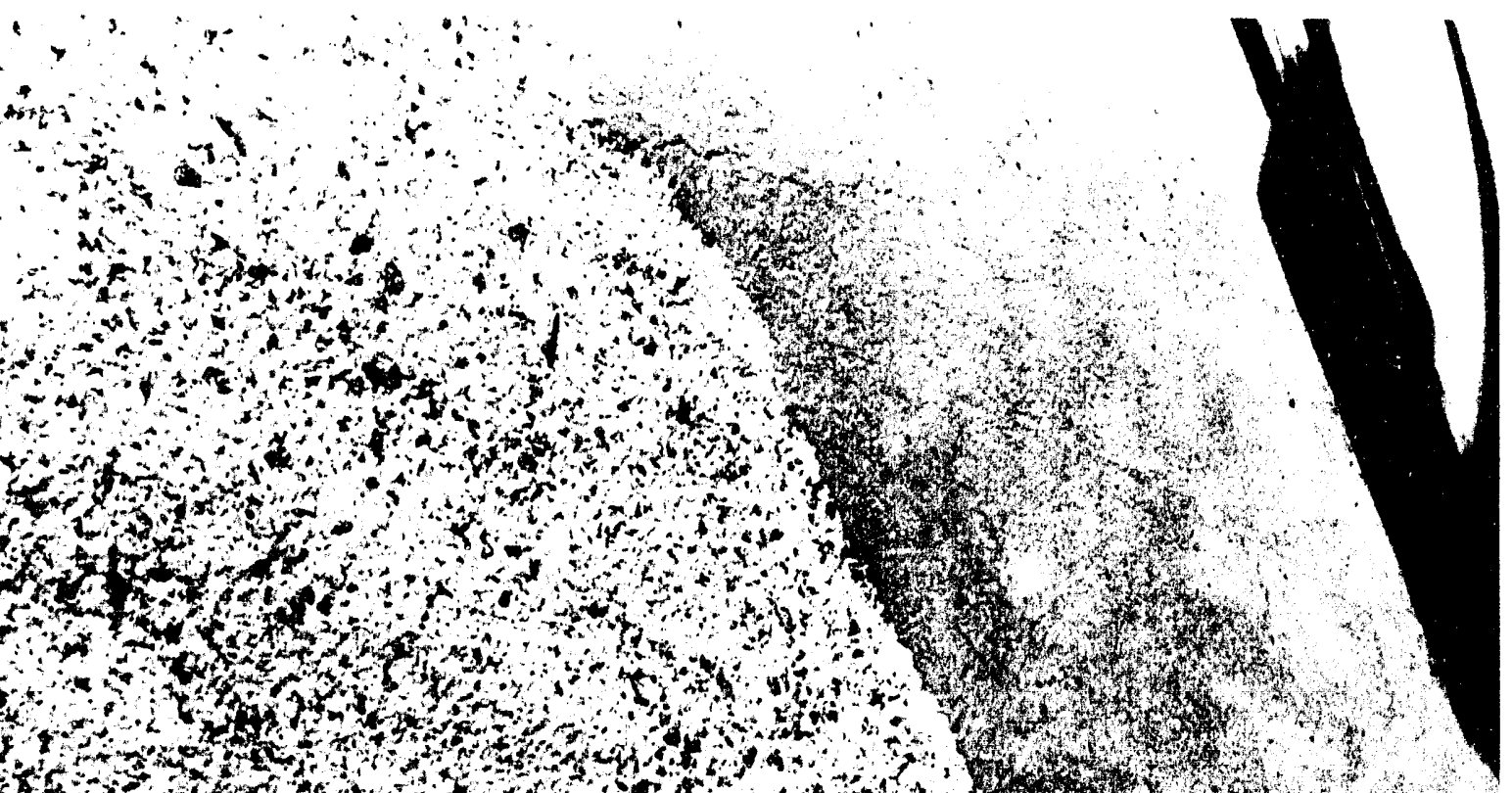

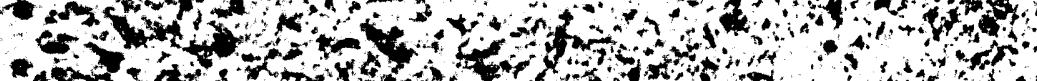

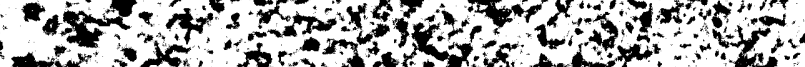
19.

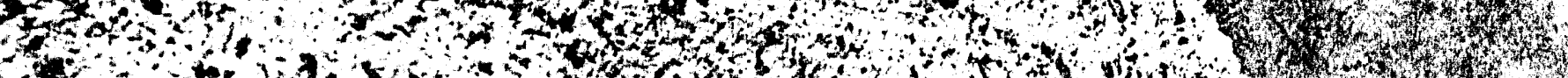

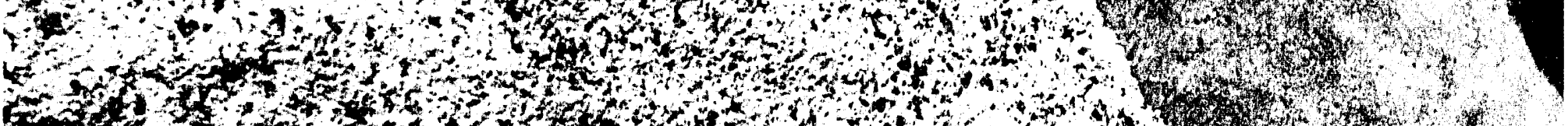

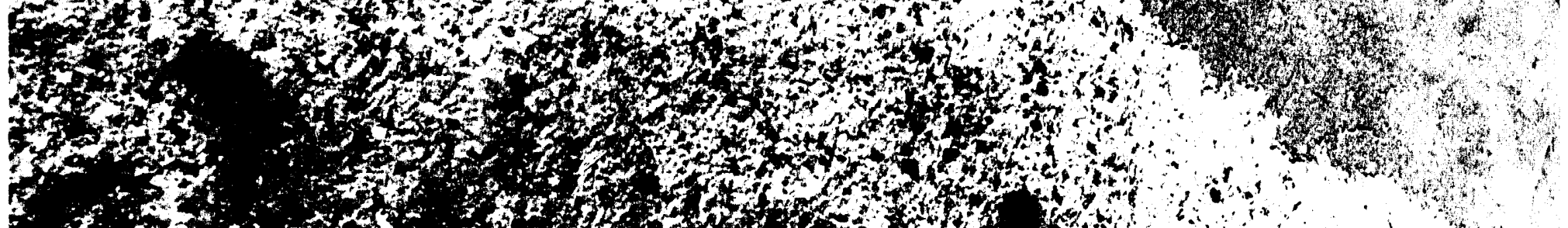

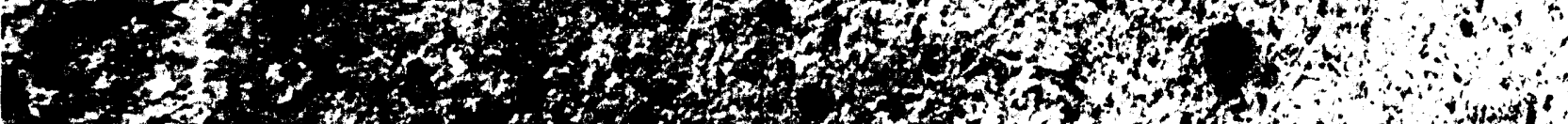

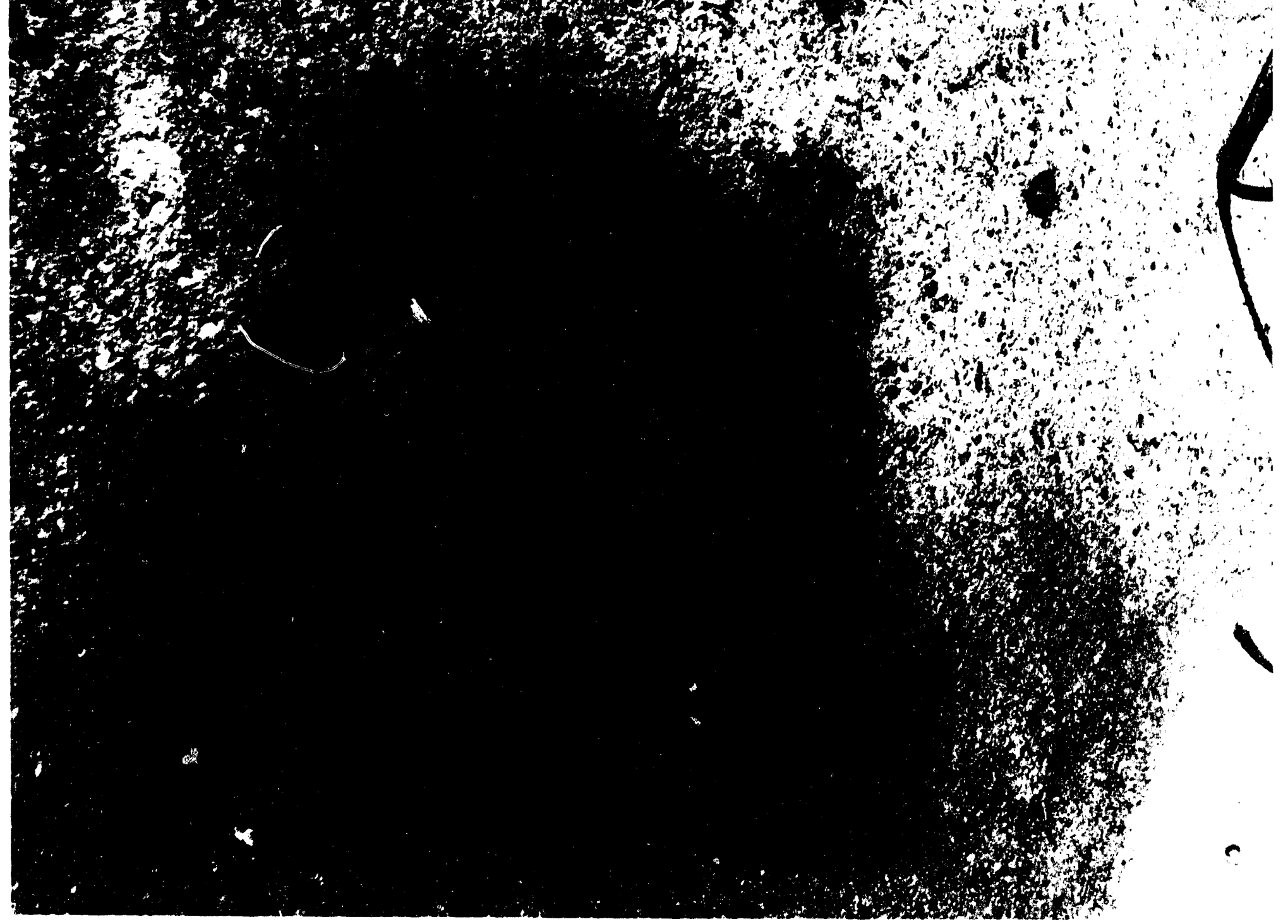


Page 16 of 36

This page intentionally left blank 
Figure 6. Delamination of patching material on Tank 39 roof top. 


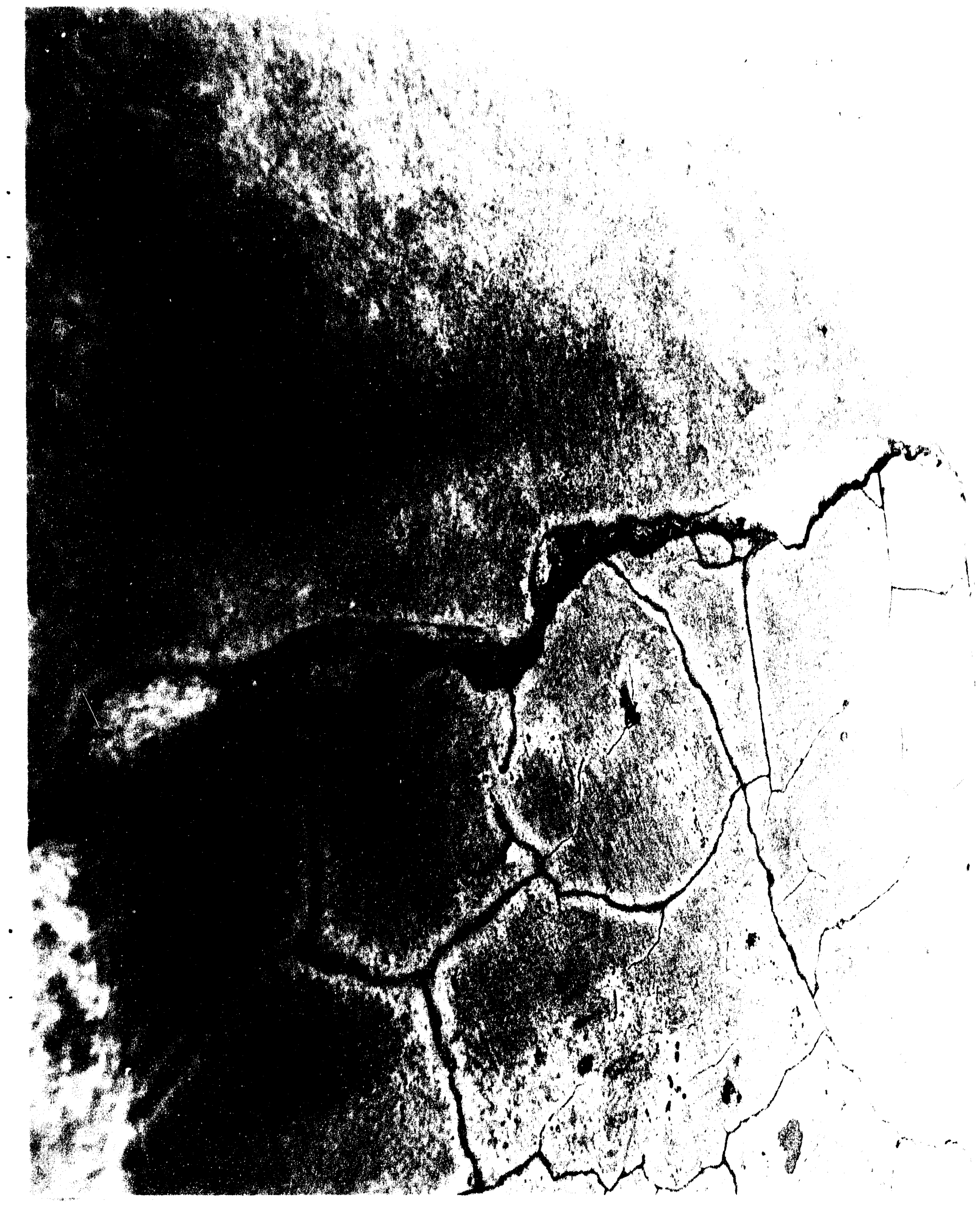


Figure 7. Operations to remove concrete slab from the Tank 34 roof top. 


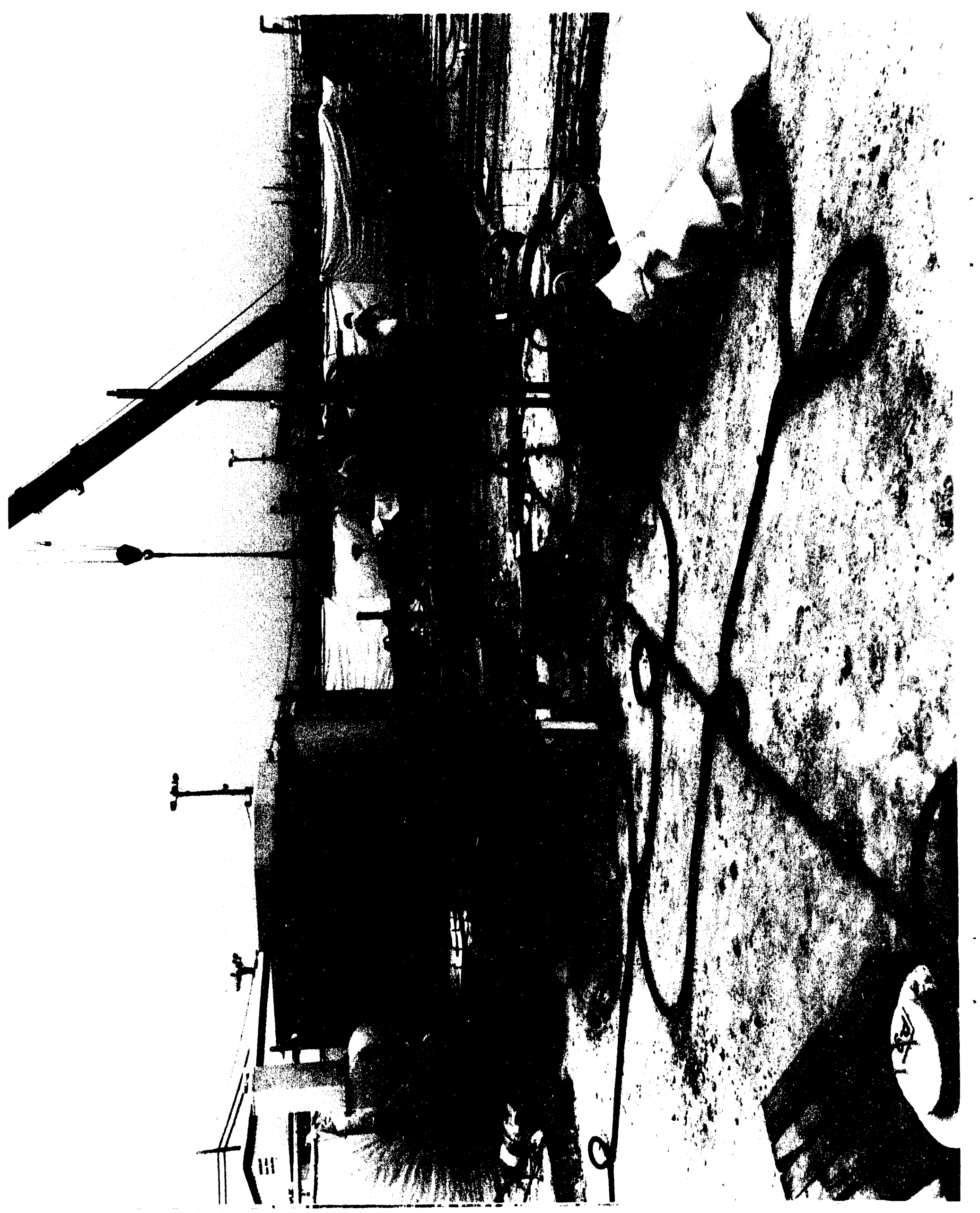


Figure 8. Concrete dome inside Tank 22. Note that the wood form marks show now evidence of degradation. 


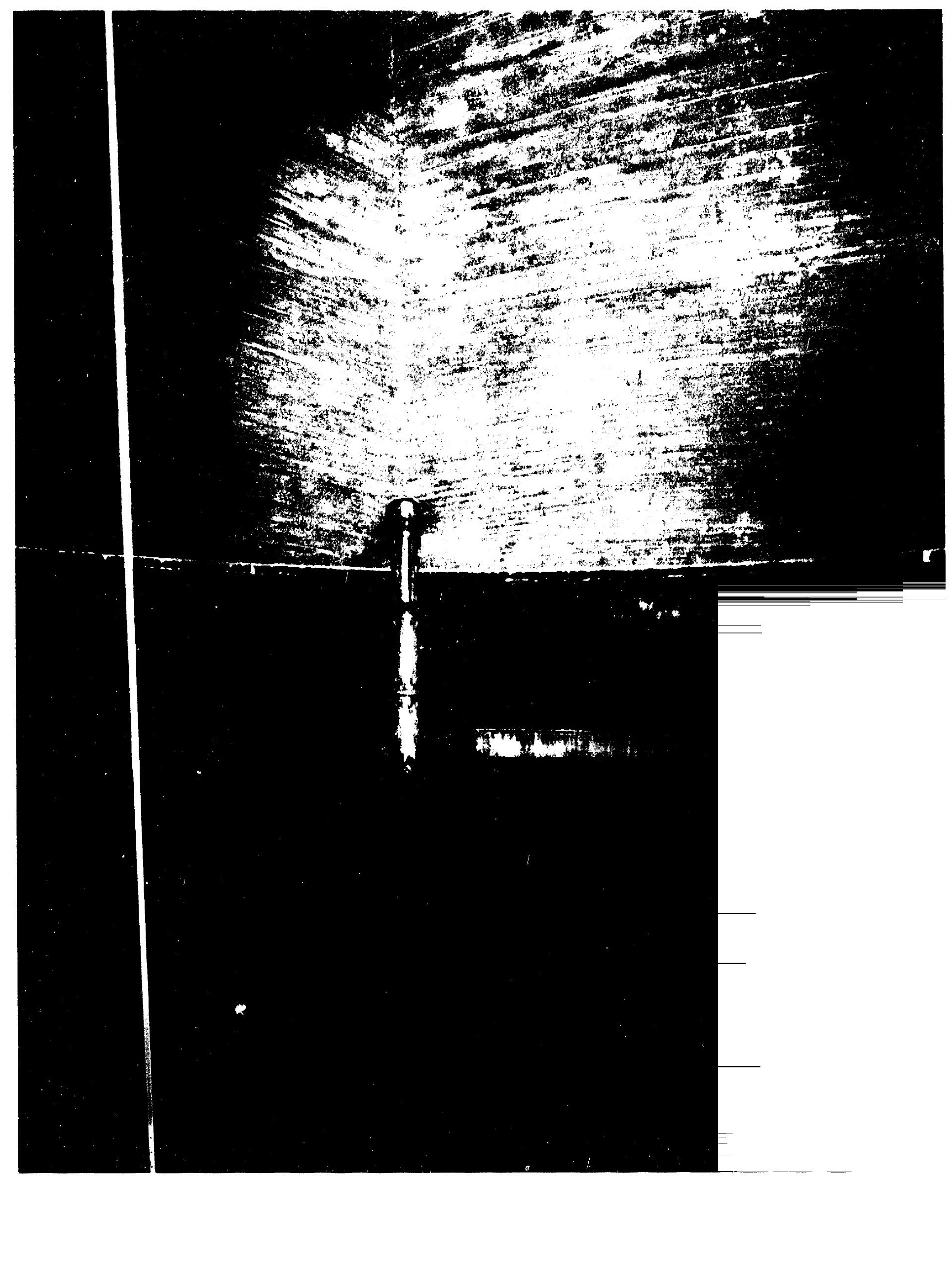


This page intentionally left blank 
Figure 9. Evidence of calcite leaching inside Tank 23. 


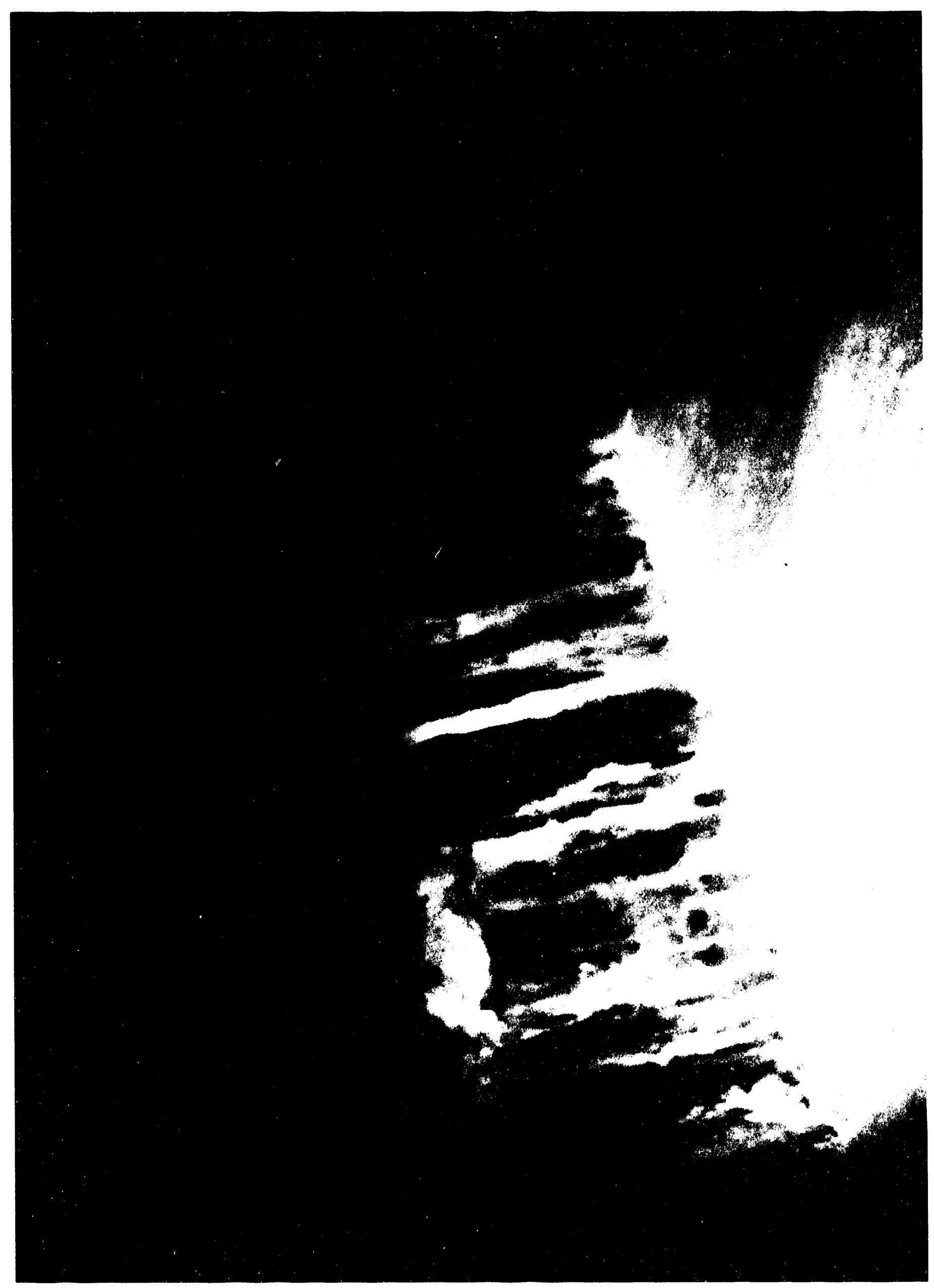




\section{Appendix I Observations of the Concrete Roofs of Type III Waste Tanks}

Descriptive summaries of the concrete roof tops were prepared for each Type III waste tank. Comments on the general appearance of the concrete along with specific locations of cracks, patches and trenches, etc., were noted. Following the descriptive summaries are diagrams which show the approximate locations of the defects. The numbers on the diagrams correspond with the numbers listed in the descriptive summaries.

\section{Descriptive Summaries}

\section{Tank 25F}

General: The paint on the concrete is delaminating in places. No spills appear to have occurred. Slurry pumps are present on the tank top. The overall condition of the concrete is very good.

Particular:

1- 6'-8' long thin cracks

2- Deep cracks around $\mathrm{C}-1$ riser

3- 8'-10' long crack; has some branches

2. Tank $26 \mathrm{~F}$

General: Observed a honeycomb like network of thin cracks over the entire tank top. The cracks did not appear to have any depth. Some scarified areas had not been patched. The overall condition of the concrete is very good.

Particular:

1-12' area where $1 / 4$ " of concrete has been scarified off and not patched.

2 - Top 1/8" of patching material appears to be delaminating in this area.

3. Tank 27F

General: Overall condition of the concrete is very good. Patching material appears to be delaminating in certain areas.

Particular:

1- Top 1/8" of patching material appears to be delaminating in this area.

2- Small amount of patching material delaminating in this area.

4. Tank 28F

General: Overall condition of the concrete is very good. Slurry pumps were present on the top of the tank. No patches were observed.

Particular: No comments.

5. Tank $29 \mathrm{H}$

General: A large amount of equipment is present on this tank top. An estimated $75 \%$ of the tank top surface has been patched. Some of the patches were delaminating. Three drainage trenches were observed on the tank top. The overall condition of the concrete is very good.

Particular:

1-20' drainage trench, $1 / 2$ " deep by 6 " wide is located here.

2- Patching material is delaminating in this area. 
3- 25 ' drainage trench, $21 / 2$ " deep by 6 " wide is located here.

4- 25 ' drainage trench, $21 / 2$ " deep by 6 " wide is located here.

\section{Tank 30H}

General: An estimated $40 \%$ of the tank top surface has been patched. Several of these patches were delaminating. Three drainage trenches were observed. The overall condition of the concrete is very good.

\section{Particular:}

1- 20' drainage trench, $21 / 2$ " deep by 5 " wide is located here. The trench passes through a riser and contains a narrow crack.

2- Patched area of approximately $20 \mathrm{ft}^{2}$.

3- $12^{\prime}$ narrow branched crack in concrete.

4- 10' drainage trench, $21 / 2$ " deep by 5 " wide is located here.

5- Patched area

6- 10' drainage trench, $21 / 2$ ' deep by 5 " wide is located here.

7- Patched area

8- Patched area

\section{Tank 31H}

General: The overall condition of the concrete is very good. Three drainage trenches were observed.

\section{Particular:}

1- 30' drainage trench, 3 " deep by 8 " wide is located here.

2- $12^{\prime}$ drainage trench, $11 / 2^{\prime \prime}$ deep by $5^{\prime \prime}$ wide is located here. The trench passes through a riser and contains a narrow crack.

3- 30' drainage trench, 3" deep by 8 " wide is located here. Narrow cracks observed in the trench.

\section{Tank $32 \mathrm{H}$}

General: An estimated $40 \%$ of the tank top surface has been patched. Six drainage trenches were observed. An exposed area of the tank wall appeared to be in good condition. The overall condition of the concrete is very good.

Particular:

1- $15^{\prime}$ drainage trench, $11 / 2$ " deep by $5^{\prime \prime}$ wide is located here.

2- 27' drainage trench, $11 / 2^{\prime \prime}$ deep by $5^{\prime \prime}$ wide is located here. A 12' drainage trench, $11 / 2^{\prime \prime}$ deep by 5 " wide is connected to the first trench.

3- Tank wall is exposed in this area.

4- 27' drainage trench, $11 / 2$ " deep by 8 " wide is located here.

5- Heavily patched area.

6- 30' drainage trench, $11 / 2^{\prime \prime}$ deep by 5 " wide is located here.

7- 12' drainage trench, 2 " deep by 5 " wide is located here.

\section{Tank 33F}

General: Overall condition of the concrete is very good. Tank top was painted and no cracks were visible.

Particular: No comments. 


\section{Tank 34F}

General: A four inch concrete slab had been placed on the tank top. The slab had degraded severely. Work was being performed to remove the slab.

\section{Particular:}

1- Branched cracks were observed near edge. These cracks contained grass and weeds.

2 - A chunk of concrete 3 ' long by $6 "$ wide had been removed from the edge of the concrete siab.

3- A chunk of concrete 5 long by 6 " wide had been removed from the edge of the concrete slab.

\section{Tank $35 \mathrm{H}$}

General: Several areas of concrete had been scarified but not patched. The overall condition of the concrete is very good.

Particular:

1- A $40 \mathrm{ft}^{2}$ area in which $1 / 4$ " of concrete has been scarified but not patched.

2- A $10 \mathrm{ft}^{2}$ area in which $1 / 4$ " of concrete has been scarified but not patched.

3- A $10 \mathrm{ft}^{2}$ area in which $1 / 4$ " of concrete has been scarified but not patched.

\section{Tank $36 \mathrm{H}$}

General: A few small areas had been scarified but not patched. Five drainage trenches were observed. The overall condition of the concrete is very good.

Particular:

1- 20' drainage trench, $1 / 2$ " deep by 8 " wide is located here.

2- $20^{\prime}$ drainage trench, $1 / 2^{\prime \prime}$ deep by 8 " wide is located here. Some narrow cracks were observed in the trench.

3- A $2 \mathrm{ft}^{2}$ area in which $1 / 4^{\prime \prime}$ of concrete has been scarified and not patched.

4-15' drainage trench, $1 / 2$ " deep by 8 " wide is located here. Some narrow cracks were observed in the trench.

5- 12 ' drainage trench, $11 / 2$ " deep by 10 " wide is located here.

6- $12^{\prime}$ drainage trench, $11 / 2^{\prime \prime}$ deep by $10^{\prime \prime}$ wide is located here. Some narrow cracks were observed in the trench.

7- A $2 \mathrm{ft}^{2}$ area in which 1/4" of concrete has been scarified but not patched.

\section{Tank $37 \mathrm{H}$}

General: An estimated $60 \%$ of the tank top had been scarified but not patched. Bolts which were assumed to be supports for the risers were protruding from the scarified areas. Narrow cracks were observed in the scarified areas. One trench was observed. The overall condition of the concrete is very good. Note: On a return visit in October 1993, it was observed that all the scarified areas had been patched.

Particular:

1- A $200 \mathrm{ft}^{2}$ area in which 1/4" of concrete has been scarified but not patched.

2- A $200 \mathrm{ft}^{2}$ area in which $1 / 4$ " of concrete has been scarified but not patched. Some narrow cracks observed in this area.

3-20' drainage trench, $21 / 2$ " deep by 6 " wide is located here.

4- $\mathrm{A} 60 \mathrm{ft}^{2}$ area in which 1/4" of concrete has been scarified but not patched. 


\section{Tank $38 \mathrm{H}$}

General: Several areas of the tank had been patched. Some patches were observed to be delaminating. The overall condition of the concrete is very good.

Particular:

1- Heavily patched area.

2- 8' long narrow crack emanating from riser E1.

3- Heavily patched area.

4- Heavily patched area.

\section{Tank $39 \mathrm{H}$}

General: An estimated $50 \%$ of the tank top surface has been patched. Some of these patches were delaminating. The overall condition of the concrete is very good.

Particular:

1- Heavily patched area.

2- A $12 \mathrm{ft}^{2}$ patched area is delaminating severely.

3- Heavily patched area.

4- Heavily patched area.

5- Heavily patched area.

16. Tank $40 \mathrm{H}$

General: An estimated $30 \%$ of the concrete surface has been scarified but not patched. The overall condition of the concrete is very good.

Particular:

1- Several 1' diameter areas which have been scarified but not patched.

2- Heavily scarified areas that have not been patched.

17. Tank $41 \mathrm{H}$

General: Some small patched and unpatched areas were observed. The tank appears to be better maintained than most. The overall condition of the concrete is very good.

Particular:

1- Heavily patched area.

2- A $20 \mathrm{ft}^{2}$ area which has been scarified but not patched.

18. Tank $42 \mathrm{H}$

General: An estimated $75 \%$ of the concrete surface has been scarified but not patched. Five slurry pumps were present on the tank. A small narrow crack was observed in the wall. The overall condition of the concrete is very good.

Particular:

1- A $120 \mathrm{ft}^{2}$ area which has been scarified but not patched.

2- Patched area appears to be delaminating.

3- A $60 \mathrm{ft}^{2}$ area which has been scarified but not patched.

4- A $100 \mathrm{ft}^{2}$ area which has been scarified but not patched.

5- Narrow crack observed in concrete wall. 
19. Tank $43 \mathrm{H}$

General: A few areas of the concrete have been scarified but not patched. The overall condition of the concrete is very good.

Particular:

1- A $2 \mathrm{ft}^{2}$ area which has been scarified but not patched.

2- A $10 \mathrm{ft}^{2}$ area which has been scarified but not patched.

3- A $60 \mathrm{ft}^{2}$ area which has been scarified but not patched.

20. Tank 44F

General: Some patched areas appear to be delaminating. Cracks in the concrete surrounding the riser were evident. The overall condition of the concrete is very good.

Particular:

1- Patched area is delaminating.

2- Cracks surrounding riser were observed.

3- Deep cracks in concrete riser plug D1.

4- Deep cracks in concrete riser plug A4.

5- Patched area is delaminating.

\section{Tank $45 \mathrm{~F}$}

General: A few areas have been scarified but not patched. A few narrow cracks were observed in the concrete. The overall condition of the concrete is very good.

Particular:

1- A $5 \mathrm{ft}^{2}$ area has been scarified but not patched.

2- A $5 \mathrm{ft}^{2}$ area has been scarified but not patched.

3- Patched area is delaminating.

4- Narrow crack makes an arc around the valve house.

22. Tank $46 \mathrm{~F}$

General: A few small patched areas that were delaminating were observed. The overall condition of the concrete is very good.

Particular:

1- Small area of concrete chipped off the edge.

2- Patched area behind the valve house is delaminating.

23. Tank 47F

General: Tank appears to be well maintained. The overall condition of the concrete is very. good.

Particular:

1- Small patched area behind the valve house is delaminating.

2- Spill area

24. Tank $48 \mathrm{H}$

General: A few small areas of concrete were scarified but not patched. A large amount of equipment is present on this tank top. Tank appears well maintained. The overall condition of the concrete is very good.

Particular: 
1- A $10 \mathrm{ft}^{2}$ area of concrete has been scarified but not patched.

2- A $5 \mathrm{ft}^{2}$ area of concrete has been scarified but not patched.

25. Tank $49 \mathrm{H}$

General: Tank appears to be well maintained. The overall condition of the concrete is very good.

Particular: No comments.

26. Tank $50 \mathrm{H}$

General: A large amount of equipment is present on this tank top. Tank appears to be well maintained. The overall condition of the concrete is very good.

Particular: No comments.

27. Tank $51 \mathrm{H}$

General: A few small areas which had been scarified but not patched. The overall condition of the concrete is very good.

Particular:

1- A $20 \mathrm{ft} 2$ area of concrete has been scarified but not patched.

2- A narrow crack was observed in the wall. 


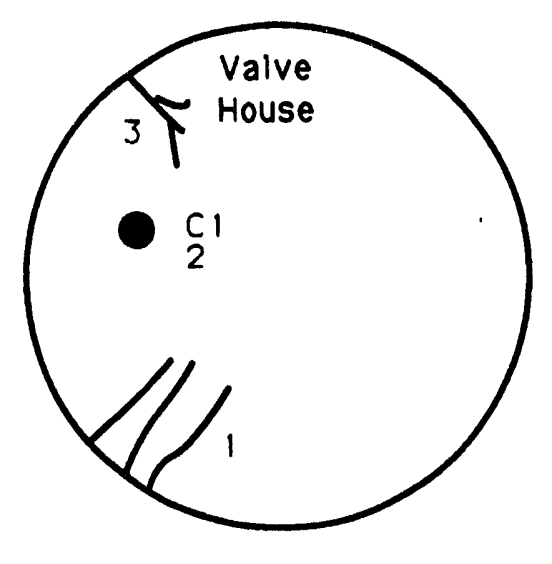

$$
\text { Tank *25 }
$$

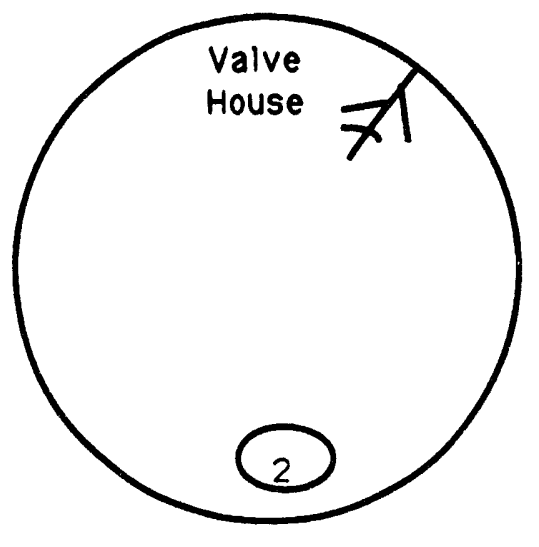

Tank * 27

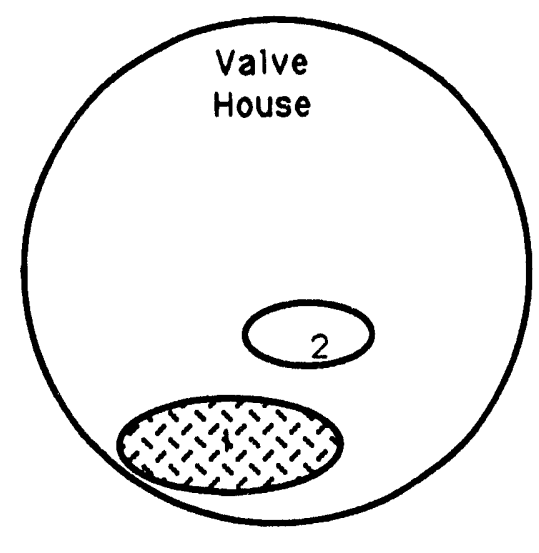

Tank $* 26$

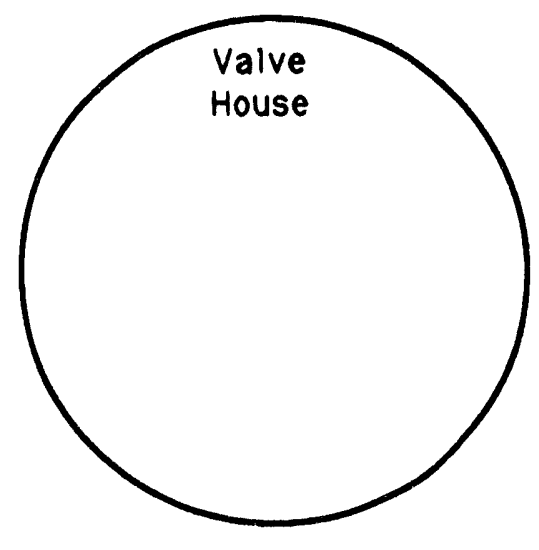

Tank $\# 28$

Figure A.1. Diagrams of Tanks 25-28F. 


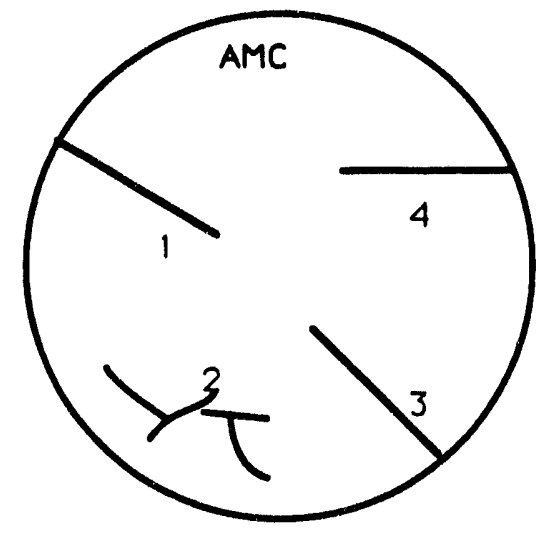

Tank $* 29$

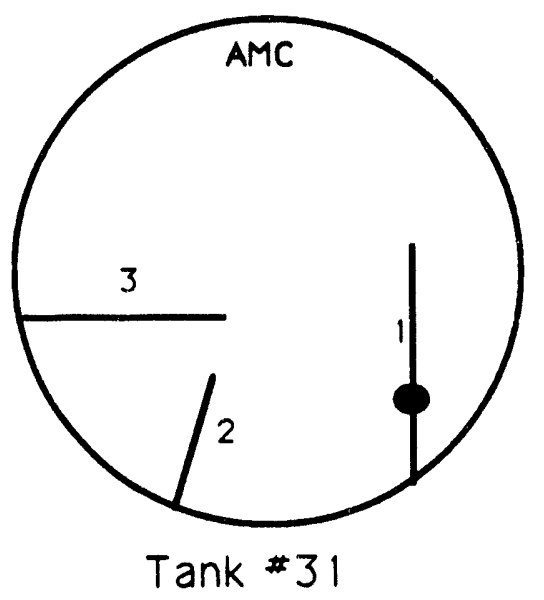

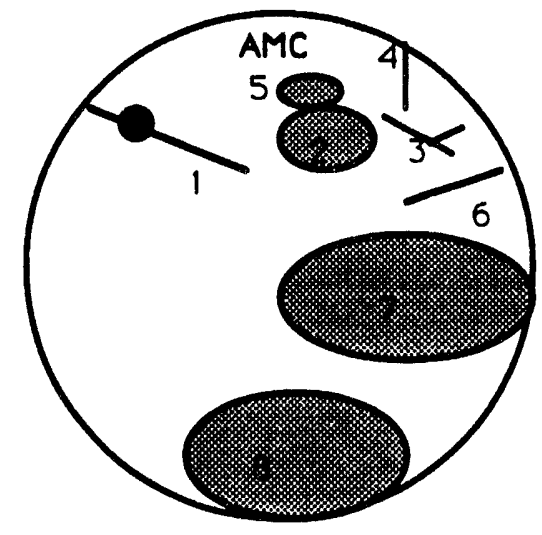

Tank $\# 30$

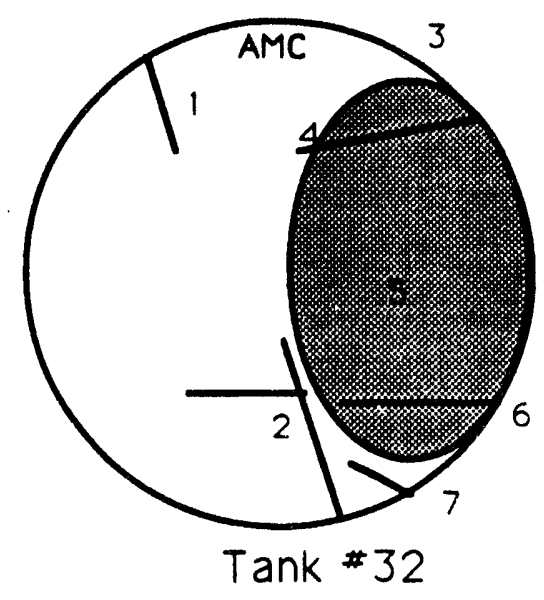

Figure A.2. Diagrams of Tanks 29-32H. 
Page 32 of 36

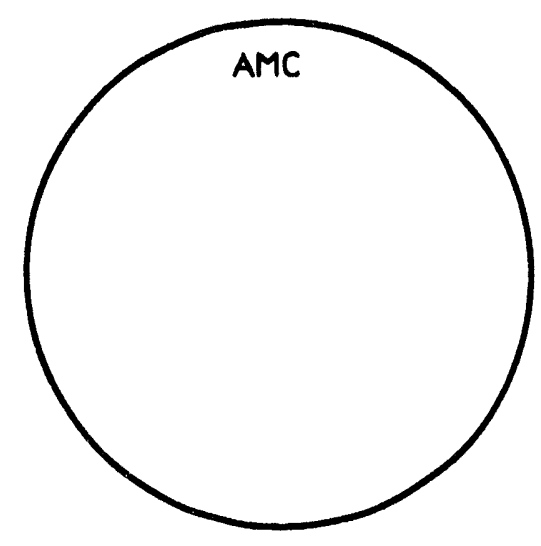

Tank $\# 33$

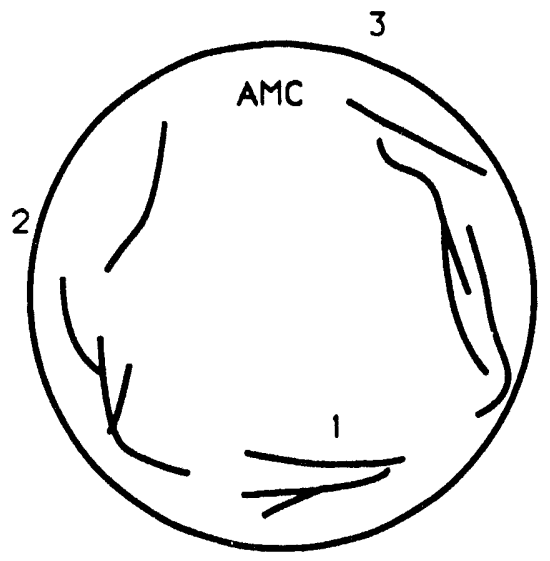

Tank $* 34$

Figure A.3. Diagrams of Tanks 33-34F 

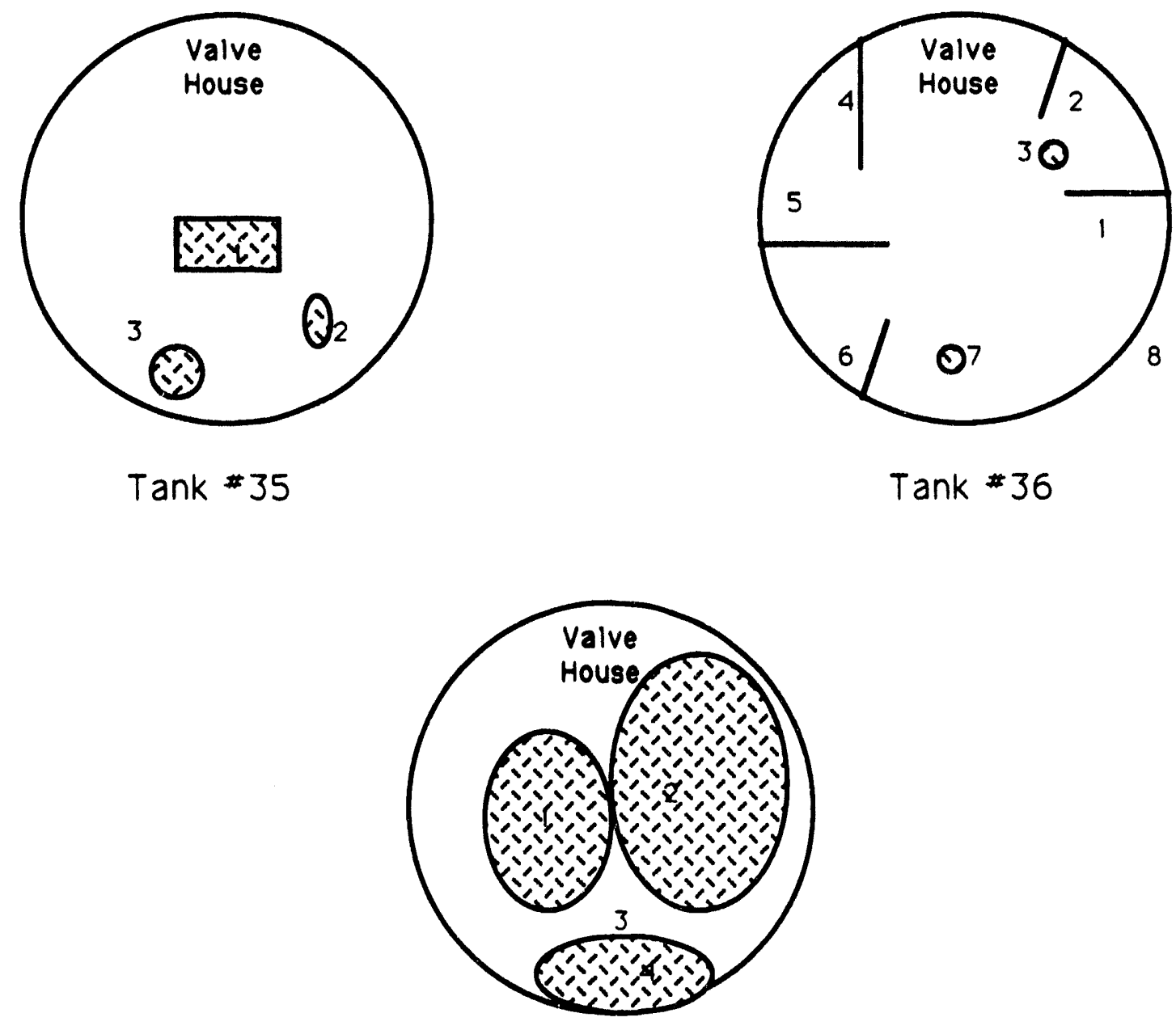

Tank $* 37$

Figure A.4. Diagrams of Tanks 35-37H. 
WSRC-TR-93-761

Page 34 of 36

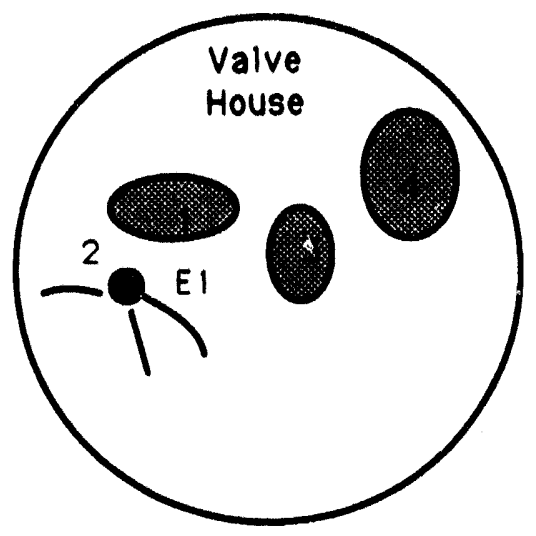

$$
\text { Tank } * 38
$$

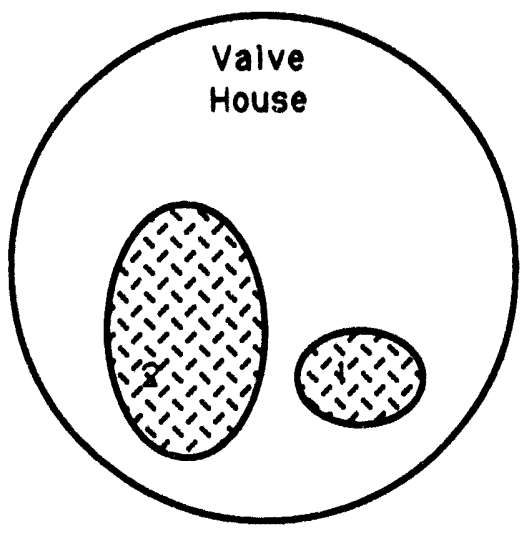

$$
\text { Tank } * 40
$$

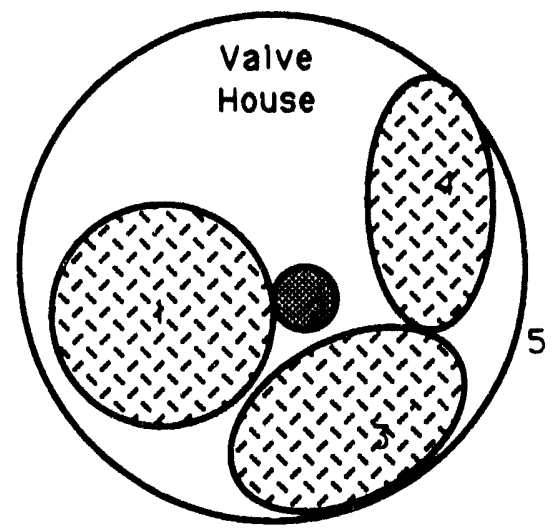

Tank $\# 42$
UNCLASSIFIED

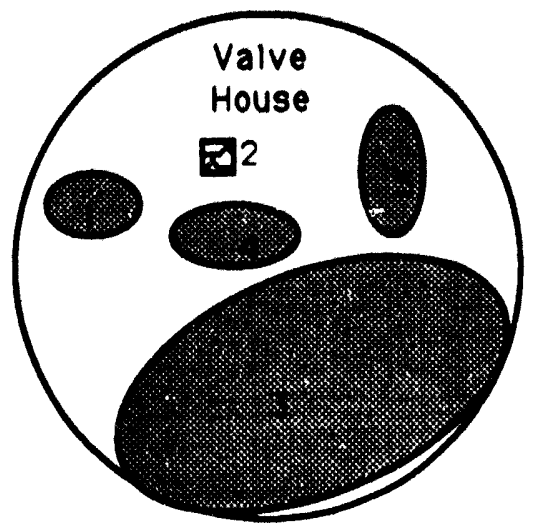

Tank " 39

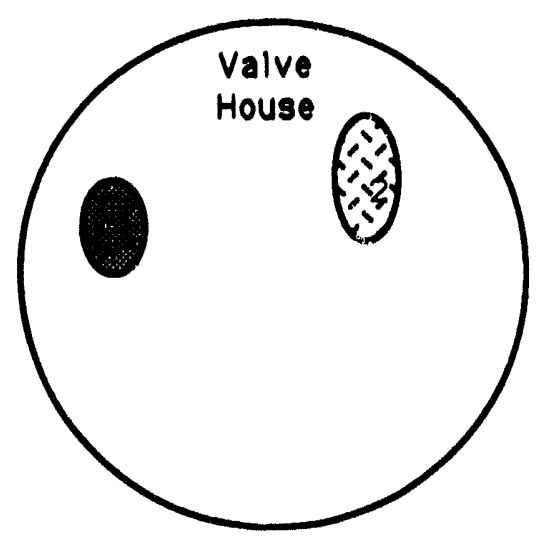

Tank * 41

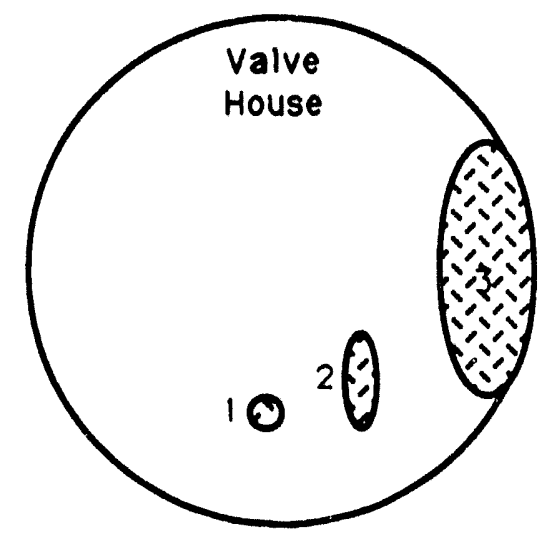

Tank $* 43$

Figure A.5. Diagrams of Tanks 38-43. 

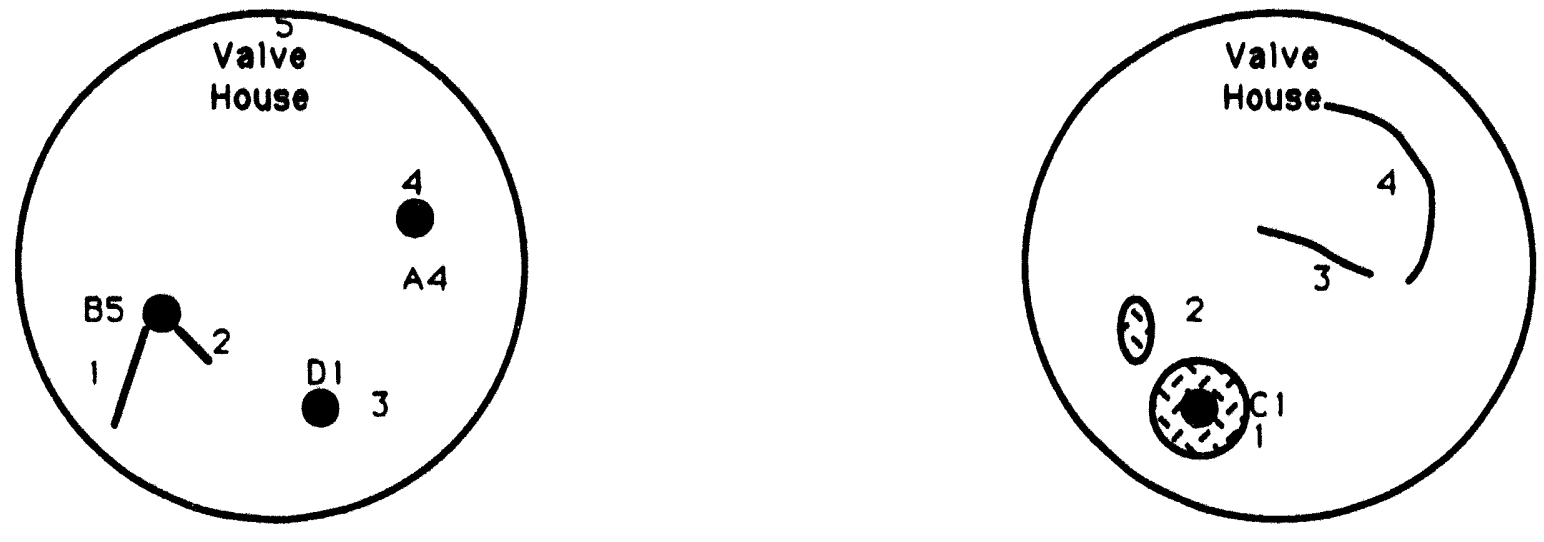

$$
\text { Tank } * 44
$$

$$
\text { Tank * } 45
$$
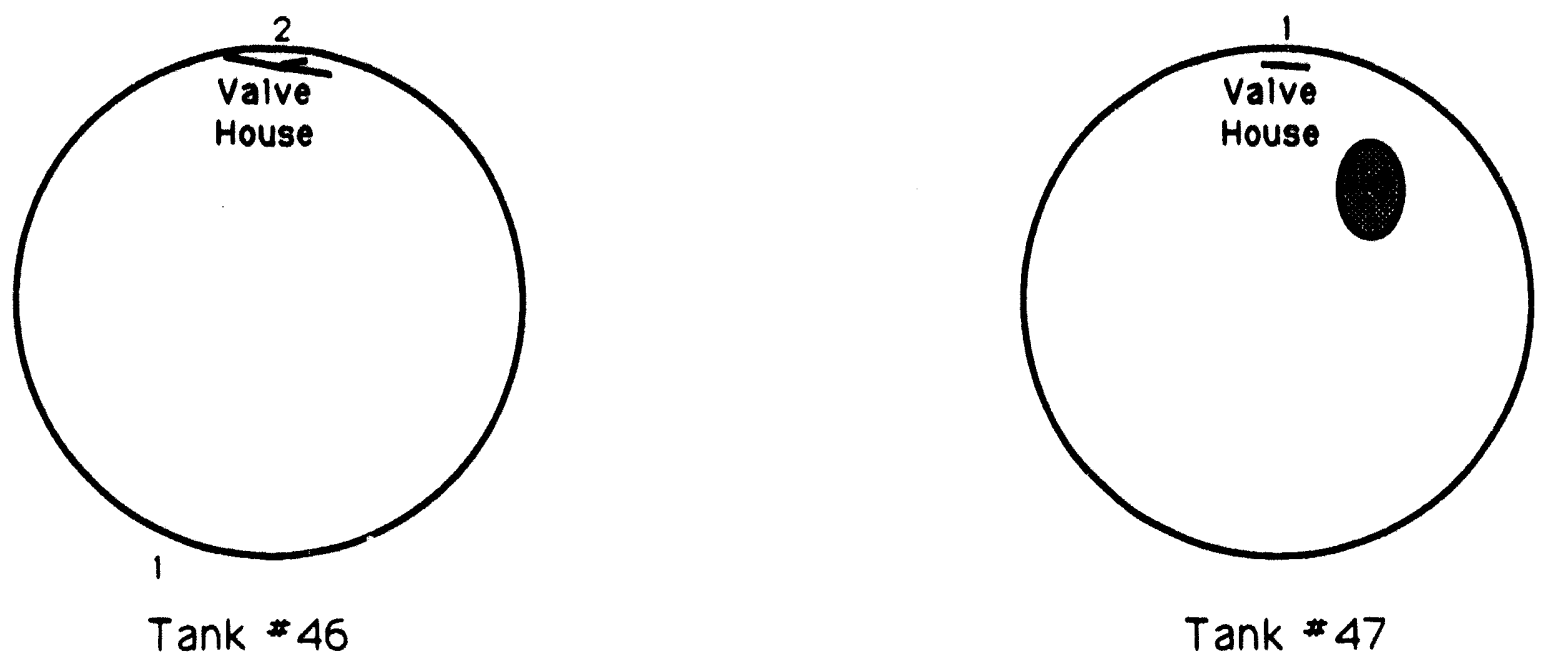

Figure A.6. Diagrams of Tanks 44-47F. 
Page 36 of 36
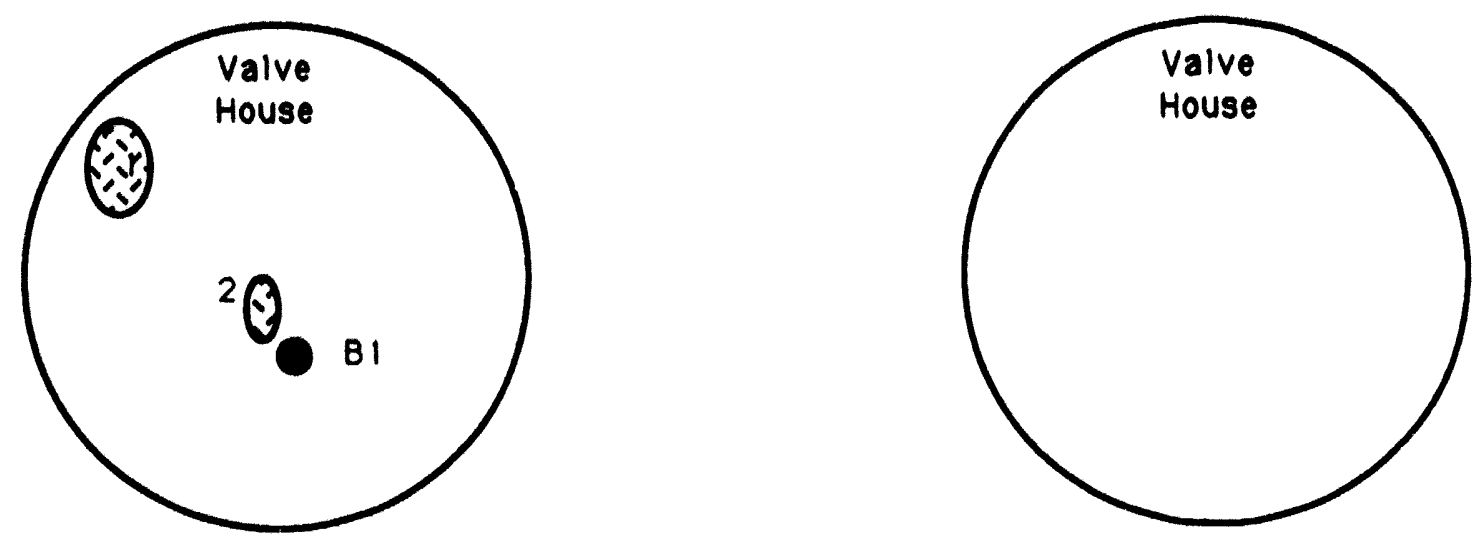

Tank $* 48$

$$
\text { Tank * } 49
$$
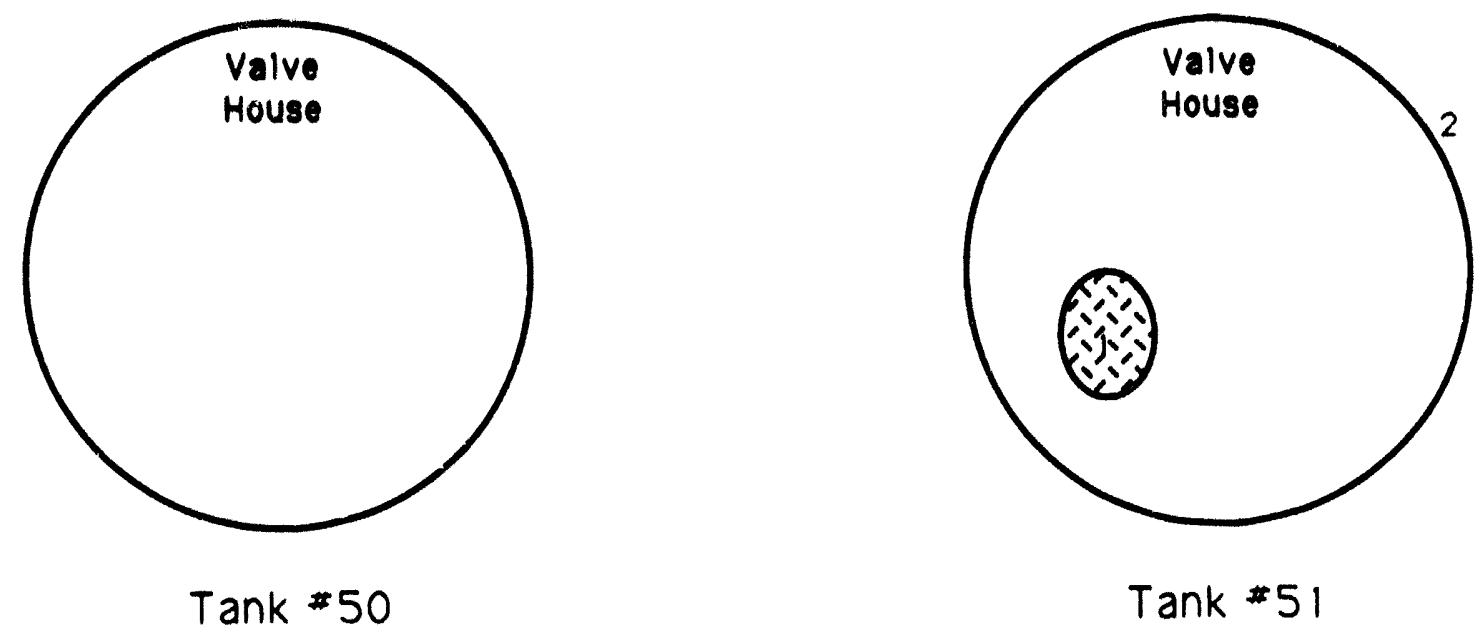

Figure A.7. Diagrams of Tanks 48-51H. 


\section{DISTRIBUTION}

\section{Westinghouse Savannah River Company}

T. M. Monahon

J. E. Marra

J. R. Chandler

F. G. McNatt, Sr.

W. R. West

M. S. Shurrab

M. E. Maryak

T. W. Houston

C. D. Cowfer

V. Cech

H. E. Flanders

I. D. Hill

M. W. Loibl

R. Ostrowski

J. D. Cohen

T. L. Capeletti

N. C. Iyer

R. L. Sindelar

B. J. Wiersma SRTC Records

MTS Files

(c/o J. M. Gantz)
$703 \mathrm{H}$

703-H

703-H

704-8H

704-8H

707-H

730-B

730-B

707-35B

740-11A

707-49B

305-1A

305-1A

707-35B

730-A

773-41A

773-A

773-41A

773-A

773-52A

773-A 


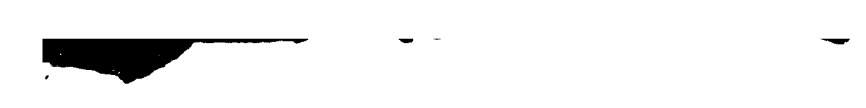

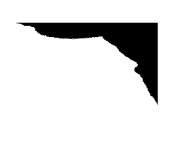
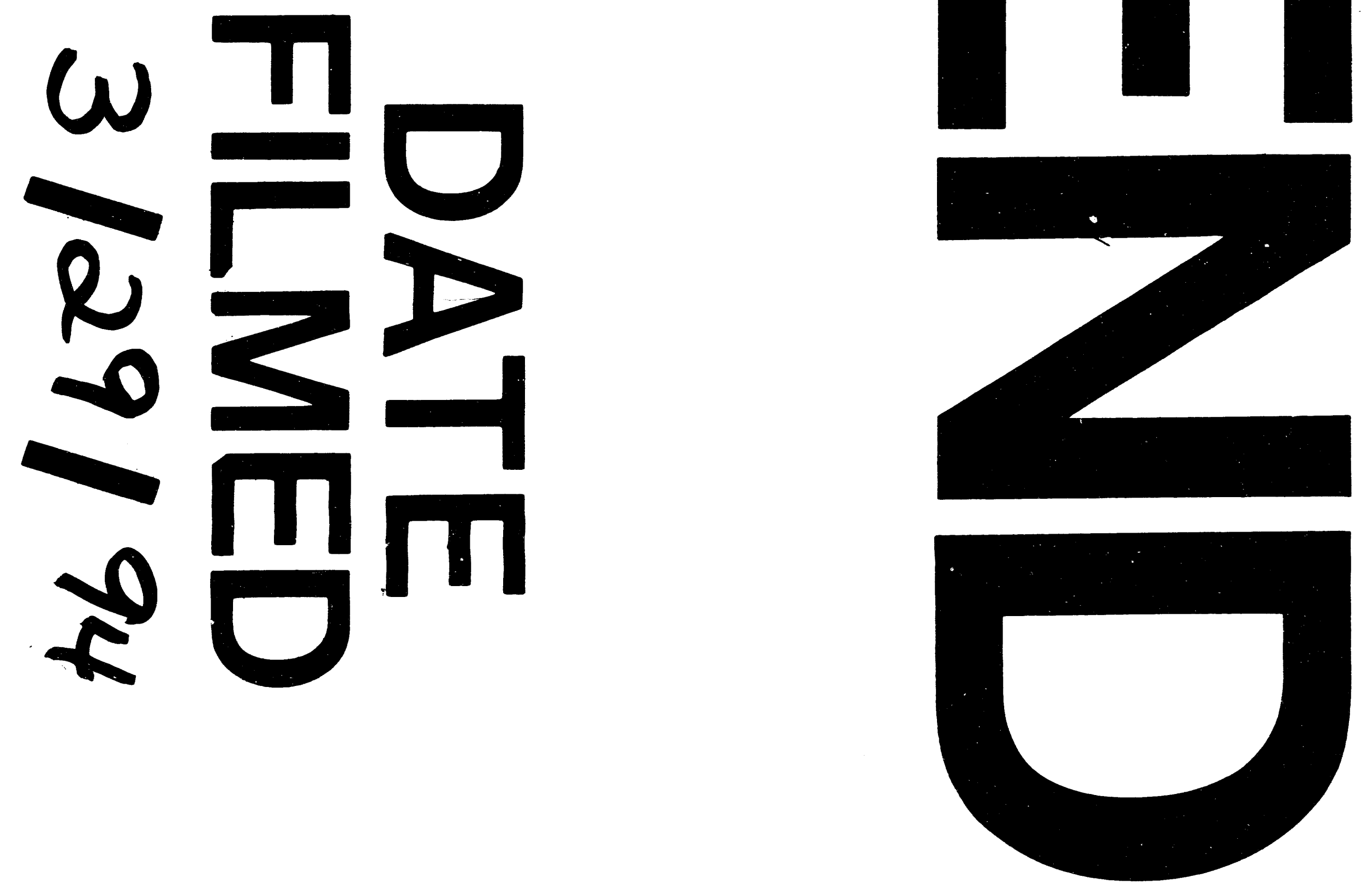